\title{
Coated zinc oxide improves intestinal immunity function and regulates microbiota composition in weaned piglets
}

\author{
Junhua Shen ${ }^{1}$, Yan Chen ${ }^{1}$, Zhisheng Wang ${ }^{1 *}$, Anguo Zhou ${ }^{1}$, Miao He $^{1}$, Lei Mao ${ }^{1}$, Huawei Zou ${ }^{1}$, \\ Quanhui Peng ${ }^{1}$, Bai Xue ${ }^{1}$, Lizhi Wang ${ }^{1}$, Xiangfei Zhang ${ }^{1}$, Shilin $\mathrm{Wu}^{2}$ and Yong $\mathrm{Lv}^{2}$ \\ ${ }^{1}$ Institute of Animal Nutrition, Sichuan Agricultural University, Ya'an 625014, People's Republic of China \\ ${ }^{2}$ Guangzhou Wisdom Bio-Technology Company Limited, Guangzhou 510663, People's Republic of China
}

(Submitted 18 September 2013 - Final revision received 15 January 2014 - Accepted 20 January 2014 - First published online 10 March 2014)

\section{Abstract}

The present study was conducted to test the hypothesis that low concentrations of coated $\mathrm{ZnO}$, as a substitute for a high concentration of $\mathrm{ZnO}(2250 \mathrm{mg} \mathrm{Zn/kg})$, could improve intestinal immunity function and regulate microbiota composition, thus alleviating the incidence of diarrhoea in weaned piglets. A total of eighty-four cross-bred piglets, weaned at an age of 28 (sEm 1) d, were allocated randomly, on the basis of average initial body weight $(7.72(\operatorname{sem} 0.65) \mathrm{kg}$ ), to seven treatment groups as follows: a $250 \mathrm{mg} \mathrm{Zn} \mathrm{(ZnO)/kg} \mathrm{group} \mathrm{(low} \mathrm{Zn;} \mathrm{LZ)}$ and a $2250 \mathrm{mg} \mathrm{Zn} \mathrm{(ZnO)/kg} \mathrm{group} \mathrm{(high} \mathrm{Zn}$; HZ) that were offered diets containing $\mathrm{ZnO}$ at 250 and $2250 \mathrm{mg} \mathrm{Zn} / \mathrm{kg}$, respectively; and five experimental groups in which coated $\mathrm{ZnO}$ was added at $250,380,570,760$ and $1140 \mathrm{mg} \mathrm{Zn/kg}$ basal diet, respectively. The trial lasted 2 weeks. The results indicated that, compared with $\mathrm{LZ}$ treatment, supplementation with coated $\mathrm{ZnO}$ at $380 \mathrm{or} 570 \mathrm{mg} \mathrm{Zn} / \mathrm{kg}$ reduced $(P<0.05)$ diarrhoea index, increased $(P<0.05)$ duodenal villus height and the ratio of villus height:crypt depth, up-regulated $(P<0.05)$ the gene expression of insulin-like growth factor 1 , zonula occludens protein- 1 , occludin, $I L-10$ and transforming growth factor $\beta 1$, and elevated $(P<0.05)$ secretory IgA concentration in the jejunal mucosa. Microbiota richness and the Shannon diversity index were also decreased $(P<0.05)$. Furthermore, piglets in the group fed coated $\mathrm{ZnO}$ at 380 or $570 \mathrm{mg} \mathrm{Zn/kg} \mathrm{did} \mathrm{not} \mathrm{differ} \mathrm{from} \mathrm{those} \mathrm{in} \mathrm{the} \mathrm{HZ-fed}$ group in relation to the aforementioned parameters. Collectively, a low concentration of coated $\mathrm{ZnO}(380 \mathrm{or} 570 \mathrm{mg} \mathrm{Zn/kg})$ can alleviate the incidence of diarrhoea by promoting intestinal development, protecting the intestinal mucosal barrier from damage, stimulating the mucosal immune system and regulating the microbiota composition.

Key words: Coated zinc oxide: Diarrhoea: Intestinal immunity: Microbiota composition

The early weaning process of piglets is always followed by weaning stress, and diarrhoea is one of the main symptoms of stress. It has been reported that 10 million piglets die of diarrhoea annually worldwide, resulting in $11 \%$ mortality in post-weaning piglets ${ }^{(1)}$. Newly weaned piglets always encouter psychosocial and physical stressors, such as maternal and littermate separation, and changes of diet and environment ${ }^{(2)}$. As nutrition is one of the major factors causing stress, nutritional regulation plays an important role in alleviating postweaning diarrhoea ${ }^{(3)}$. $\mathrm{Zn}$, one of the essential trace elements in the animal body, takes part in the synthesis of over 300 enzymes, and is intimately associated with gut development and immune function. Pharmacological concentration of inorganic $\mathrm{Zn}$, especially $\mathrm{ZnO}$, is widely used in the diets of piglets in the swine industry, due to its effects on enhancing growth performance and alleviating the incidence of diarrhoea ${ }^{(4,5)}$. However, the addition of a high dose of $\mathrm{ZnO}$ to the diets of weaned piglets has been criticised worldwide, and many countries have limited or banned the use of such high dose of $\mathrm{ZnO}$ in weaned piglets owing to severe environmental pollution caused by a large amount of $\mathrm{Zn}$ excretion ${ }^{(6)}$.

$\mathrm{ZnO}$ is an amphoteric molecule and almost insoluble in water, but has a higher solubility at acid $\mathrm{pH}$. When $\mathrm{ZnO}$ in the diet reaches the stomach of piglets where the $\mathrm{pH}$ value is about 3.5-4.5, most insoluble $\mathrm{ZnO}$ is transformed into $\mathrm{Zn}$ ions, thus just a small amount of $\mathrm{ZnO}$ can work in the intestine, which is the important site of its action. In addition, compared with other inorganic forms of $\mathrm{Zn}, \mathrm{ZnO}$ has been found

Abbreviations: CZ250, piglets fed at a dose of $250 \mathrm{mg} \mathrm{Zn} \mathrm{(coated} \mathrm{ZnO)/kg} \mathrm{basal} \mathrm{diet;} \mathrm{CZ380,} \mathrm{piglets} \mathrm{fed} \mathrm{at} \mathrm{a} \mathrm{dose} \mathrm{of} 380 \mathrm{mg} Z \mathrm{Zn}$ (coated ZnO)/kg basal diet; CZ570, piglets fed at a dose of $570 \mathrm{mg} \mathrm{Zn} \mathrm{(coated} \mathrm{ZnO)/kg} \mathrm{basal} \mathrm{diet;} \mathrm{CZ760,} \mathrm{piglets} \mathrm{fed} \mathrm{at} \mathrm{a} \mathrm{dose} \mathrm{of} 760 \mathrm{mg}$ Zn (coated ZnO)/kg basal diet; CZ1140, piglets fed at a dose of $1140 \mathrm{mg} \mathrm{Zn} \mathrm{(coated} \mathrm{ZnO)/kg} \mathrm{basal} \mathrm{diet;} \mathrm{DGGE,} \mathrm{denaturing} \mathrm{gradient} \mathrm{gel} \mathrm{electrophoresis;} \mathrm{ETEC,} \mathrm{enterotoxigenic} \mathrm{Escherichia} \mathrm{coli;} \mathrm{HZ,} \mathrm{piglets}$ fed at a dose of $2250 \mathrm{mg} \mathrm{Zn} \mathrm{(ZnO)/kg} \mathrm{basal} \mathrm{diet;} \mathrm{IGF-1,} \mathrm{insulin-like} \mathrm{growth} \mathrm{factor} \mathrm{1;} \mathrm{LZ,} \mathrm{piglets} \mathrm{fed} \mathrm{at} \mathrm{a} \mathrm{dose} \mathrm{of} \mathrm{250} \mathrm{mg} \mathrm{Zn} \mathrm{(ZnO)/kg} \mathrm{basal} \mathrm{diet;}$ SIgA, secretory IgA; TGF- $\beta 1$, transforming growth factor $\beta 1$; TJ, tight junction; ZO-1, zonula occludens protein-1. 
to have a better effect on the resistance to intestinal diseases $^{(7)}$, which probably means that besides $\mathrm{Zn}$ ions, the $\mathrm{ZnO}$ molecule itself also plays a crucial role in alleviating the incidence of diarrhoea. This is the reason why a high dose of $\mathrm{ZnO}$ is added into the diets of piglets. If $\mathrm{ZnO}$ is processed to make its dissociation percentage to reduce in the stomach, a larger amount of $\mathrm{ZnO}$ can reach the intestine, thereby a lower dose of $\mathrm{ZnO}$ could be used in the diet. Some studies have proved that this is entirely feasible. As clay mineral carriers, such as diosmectite and zeolite, have high ion-exchange and adsorption capacities, they can be used as a means of controlling the release of $\mathrm{ZnO}$ in the gastrointestinal tract; therefore, the addition levels of $\mathrm{ZnO}$ can be reduced to $500-900 \mathrm{mg} \mathrm{Zn} / \mathrm{kg}^{(8,9)}$. However, the amount of $\mathrm{ZnO}$ supported by these carriers is still obviously supra-physiological for piglets. A better method should be sought to further decrease the addition levels of $\mathrm{ZnO}$. Enteric coating is a common technology to protect oral medications against the effects of stomach juices in the field of pharmacy. This technology has been used in the field of feed additives for a long time. Under the protection of outer enteric coating, the inner core component can safely pass through the stomach. We have conducted an in vitro experiment on the dissociation percentage of coated $\mathrm{ZnO}$ and $\mathrm{ZnO}$ (uncoated) in the stomach digesta of weaned piglets. The results showed that the dissociation percentage of coated $\mathrm{ZnO}$ in stomach is $25.03 \%$, while that of $\mathrm{ZnO}$ (uncoated) is $85.26 \%$, which indicated that coating can well protect $\mathrm{ZnO}$ from being dissociated in the stomach. At alkaline $\mathrm{pH}$ (i.e. in the gastrointestinal tract), the coating would be gradually degraded and the inner $\mathrm{ZnO}$ would be released slowly in the entire intestine. Kim et al. ${ }^{(10)}$ reported that a low dose of coated $\mathrm{ZnO}(100 \mathrm{mg} \mathrm{Zn} / \mathrm{kg}$ ) achieved the same effect as with a high dose of $\mathrm{ZnO}(3000 \mathrm{mg} \mathrm{Zn} / \mathrm{kg}$ ) in alleviating post-weaning diarrhoea ${ }^{(11)}$. This observation demonstrated that the use of enteric coating is an ideal method to reduce the addition levels of $\mathrm{ZnO}$. It is known that post-weaning diarrhoea is closely associated with the damage of intestinal immunity function and microbiota composition; however, little study has been carried out to investigate the effects of coated $\mathrm{ZnO}$ on these two aspects. Therefore, in the present study, we hypothesised that supplementation of a low dose of coated $\mathrm{ZnO}$, as a potential substitute for a high dose of $\mathrm{ZnO}$, could alleviate the incidence of diarrhoea in weaned piglets by improving intestinal immunity function and regulating microbiota composition. To test this hypothesis, we evaluated the effects of coated $\mathrm{ZnO}$ on growth performance and diarrhoea index in piglets. Furthermore, intestinal morphology and mRNA expression levels of insulin-like growth factor 1 (IGF-1), tight junction (TJ; zonula occludens protein-1 (ZO-1) and occludin) and inflammatory cytokines (TNF- $\alpha, I L-6$, transforming growth factor $\beta 1(T G F-\beta 1)$ and $I L-10)$, and secretory IgA (SIgA) concentration in the jejunal mucosa were determined to investigate the effects of coated $\mathrm{ZnO}$ on intestinal development and immune status in piglets. Microbiota richness, the Shannon diversity index, clustering of the denaturing gradient gel electrophoresis (DGGE) profiles and the relative abundances of Lactobacillus and
Escherichia coli were also determined to assess the effects of coated $\mathrm{ZnO}$ on the intestinal microbiota composition of piglets. In addition, $\mathrm{Zn}$ concentrations in the serum, liver, kidney and faeces of weaned piglets were analysed to assess $\mathrm{Zn}$ residues in animals and environmental pollution of $\mathrm{Zn}$.

\section{Materials and methods}

The animal use and care protocol was approved by the Animal Care and Use Committee of Sichuan Agricultural University.

\section{Experimental animals and design}

A total of eighty-four cross-bred piglets (Duroc $\times$ Landrace $\times$ Yorkshire), weaned at an age of 28 (SEM 1) d, were allocated randomly, on the basis of average initial body weight $(7 \cdot 72$ (SEM 0.65$) \mathrm{kg}$ ), to one of seven dietary treatments with four replicates each. There were three pigs in each replicate placed together in an individual pen equipped with wovenwire floors, stainless-steel nipple drinkers and feeders. There were four rooms and each room contained seven pens. The room temperature was maintained at $28^{\circ} \mathrm{C}$.

Seven treatments consisted of a $250 \mathrm{mg} \mathrm{Zn}(\mathrm{ZnO}) / \mathrm{kg}$ diet (low Zn (LZ); basal diet $+250 \mathrm{mg} \mathrm{Zn} \mathrm{(ZnO)/kg),} \mathrm{a} 2250 \mathrm{mg}$ $\mathrm{Zn}(\mathrm{ZnO}) / \mathrm{kg}$ diet (high $\mathrm{Zn}(\mathrm{HZ})$; basal diet $+2250 \mathrm{mg} \mathrm{Zn}$ $(\mathrm{ZnO}) / \mathrm{kg})$ and five experimental diets in which coated $\mathrm{ZnO}$ (CZ) (Guangzhou Wisdom Bio-Tech Company Limited) was added at 250 (CZ250), 380 (CZ380), 570 (CZ570), 760 (CZ760) and 1140 (CZ1140) $\mathrm{mg} \mathrm{Zn} / \mathrm{kg}$ of basal diet, respectively. No other $\mathrm{Zn}$ source was added into the basal diet.

\section{Diets and management}

The basal diet was formulated on the basis of nutrient requirements for weaned piglets ${ }^{(12)}$ (Table 1). The $\mathrm{ZnO}$ used in the study was a feed-grade source.

The trial was carried out at the Research Base of the Institute of Animal Nutrition in Sichuan Agricultural University. It included an adaptation period of $5 \mathrm{~d}$ adaptation and an experimental period of $14 \mathrm{~d}$ during which piglets were allowed for ad libitum access to diets and water. The diets were added to the feeders four times daily $(08.00,12.00,16.00$ and 20.00 hours). Individual feed consumption was determined daily throughout the duration of the trial. Initial (day 0) and final (day 14) body weights were measured after $12 \mathrm{~h}$ fasting. Response variables measured included average daily feed intake, average daily gain and feed:gain ratio. The diarrhoea index was monitored according to the previous faecal scoring system from 0 to 3 as follows: 0 , normally shaped faeces; 1 , shapeless faeces; 2 , soft faeces; 3 , liquid faeces ${ }^{(13)}$.

\section{Analysis of small-intestinal histology}

On day 14, twenty-eight piglets ( $n 4$ per treatment group) were randomly selected, and then held under general anaesthesia by an intravenous injection of $4 \%$ sodium pentobarbital solution ( $40 \mathrm{mg} / \mathrm{kg}$ body weight) and killed. After a midline laparotomy, segments of the duodenum, the middle section 
Table 1. Compositions and nutrient levels of the basal diet (air-dried basis)

\begin{tabular}{|c|c|c|c|}
\hline \multicolumn{2}{|l|}{ Composition } & \multicolumn{2}{|c|}{ Nutrient level } \\
\hline Ingredients & Proportion (\%) & Items & Content \\
\hline Maize & 51.45 & $\mathrm{DE}(\mathrm{MJ} / \mathrm{kg})$ & $14 \cdot 29$ \\
\hline Rapeseed oil & 2.00 & $\mathrm{CP}(\%)$ & $20 \cdot 19$ \\
\hline Soyabean & $22 \cdot 50$ & Lys (\%) & $1 \cdot 36$ \\
\hline Fishmeal & 3.80 & Met $(\%)$ & 0.35 \\
\hline Acid whey powder & $6 \cdot 00$ & $\mathrm{Ca}(\%)$ & $0 \cdot 80$ \\
\hline Sucrose & $2 \cdot 00$ & Total P (\%) & 0.65 \\
\hline Glucose & 3.00 & Trp/Lys & 0.18 \\
\hline Wheat bran & $2 \cdot 00$ & $\mathrm{Zn}(\mathrm{mg} / \mathrm{kg})^{*}$ & $29 \cdot 39$ \\
\hline Spray-dried plasma protein & 4.00 & & \\
\hline $\mathrm{CaHPO}_{4}$ & 1.00 & & \\
\hline $\mathrm{CaCO}_{3}$ & 0.65 & & \\
\hline $\mathrm{NaHCO}_{3}$ & 0.50 & & \\
\hline $\mathrm{NaCl}$ & $0 \cdot 20$ & & \\
\hline L-Lys $\mathrm{HCl}$ & 0.31 & & \\
\hline DL-Met & 0.02 & & \\
\hline Choline chloride & $0 \cdot 10$ & & \\
\hline Compound vitamin† & 0.08 & & \\
\hline Minerals $\ddagger$ & 0.40 & & \\
\hline
\end{tabular}

$\mathrm{DE}$, digestible energy; $\mathrm{CP}$, crude protein

${ }^{*} \mathrm{Zn}$ concentration was the measured value and others were calculated values.

†Compound vitamin provided the following per $\mathrm{kg}$ of diet: vitamin $\mathrm{A}, 10.56 \mathrm{mg}$; cholecalciferol, $0.2 \mathrm{mg}$; vitamin E, $200 \mathrm{mg}$; menadione, $40 \mathrm{mg}$; vitamin $\mathrm{B}_{1}, 16 \mathrm{mg}$; vitamin $B_{2}, 128 \mathrm{mg}$; vitamin $B_{6}, 4.8 \mathrm{mg}$; vitamin $B_{12}, 0.24 \mathrm{mg}$; D-calcium pantothenate, $200 \mathrm{mg}$; nicotinic acid, $280 \mathrm{mg}$; folic acid, $4 \mathrm{mg}$.

$\ddagger$ Minerals provided the following per $\mathrm{kg}$ of diet: $\mathrm{Fe}, 100 \mathrm{mg} / \mathrm{kg} ; \mathrm{Cu}, 10 \mathrm{mg} / \mathrm{kg} ; \mathrm{Mn}$, $10 \mathrm{mg} / \mathrm{kg} ; \mathrm{Se}, 0.3 \mathrm{mg} / \mathrm{kg} ; \mathrm{l}, 0.3 \mathrm{mg} / \mathrm{kg}$.

of the jejunum and the ileum $(20 \mathrm{~mm})$ were taken quickly, and then fixed in formalin (formaldehyde $3 \cdot 8 \%$ ). For histological analysis, the different intestinal segments $(20 \mathrm{~mm})$ were embedded in paraffin. Sections $(5 \mu \mathrm{m})$ were cut and stained with periodic acid-Schiff reagent. The stained sections were subsequently used to determine villus height $(\mu \mathrm{m})$ and crypt depth $(\mu \mathrm{m})$. For each piglet, one slide was used and the average values were taken for a minimum of four villi and crypts.

Analysis of zinc concentrations in serum, liver, kidney and faeces

On day 14, four piglets from each treatment group were randomly selected for blood sampling via the jugular vein. The blood samples were collected into $20 \mathrm{ml}$ tubes and allowed to clot at an ambient temperature (about half an hour).
Thereafter, the samples were centrifuged at $3000 \mathrm{rpm}$ for $15 \mathrm{~min}$ to obtain serum and then kept frozen until further analysis.

After twenty-eight piglets (one per replicate) were killed, liver and kidney were collected and washed with normal saline, and then stored at $-20^{\circ} \mathrm{C}$ for the determination of $\mathrm{Zn}$ concentrations. Faeces of each replication were also collected on day 14 , dried using a forced-air oven $\left(65^{\circ} \mathrm{C}\right)$ for $24 \mathrm{~h}$, and then ground to pass a $2 \mathrm{~mm}$ screen for analysis of $\mathrm{Zn}$ concentrations.

Liver, kidney and faecal samples were prepared for $\mathrm{Zn}$ analysis using nitric-perchloric acid wet digestion ${ }^{(14)}$. The analysis of $\mathrm{Zn}$ concentrations was carried out with a nov-AA400 flame atomic absorption spectrometer (Analytik Jena AG).

\section{Analysis of mucosal secretory IgA}

Jejunal mucosa samples were collected, washed with normal saline and then stored at $-80^{\circ} \mathrm{C}$ for further analysis. The samples were mixed with PBS buffer through tissue homogenate, resulting in the formation of a $10 \%$ solution. Then, SIgA concentrations were determined using the sandwich ELISA kit (Nanjing Jiancheng Biochemical Reagent Company), according to the manufacturer's instructions.

\section{RNA isolation and real-time quantitative $P C R$}

Total RNA was extracted from jejunal mucosa samples, which were triturated in liquid $\mathrm{N}_{2}$, using RNAiso Plus (Takara), according to the manufacturer's instructions. The integrity of the extracted RNA was checked by $1 \%$ agarose gel electrophoresis and visualisation of intact 185 and 285 ribosomal RNA bands under UV light. Reverse transcription was performed using the PrimeScript ${ }^{\mathrm{TM}}$ RT Reagent Kit (Takara) with a $1 \mu \mathrm{g}$ RNA sample, according to the manufacturer's instructions. Expression levels of $I G F-1, Z O-1$, occludin, $I L-6$, $T N F-\alpha, I L-10$ and $T G F-\beta 1$ in the jejunal mucosa were analysed by real-time quantitative PCR with SYBR Premix Ex Taq ${ }^{\mathrm{TM}}$ II (Takara), which was performed on complementary DNA samples in ninety-six-well optical plates on a CFX96 ${ }^{\mathrm{TM}}$ RealTime System (Bio-Rad). All of the primers (all the target genes and the reference gene TBP (TATA box-binding protein)) used for real-time PCR were designed using Primer Premier 5.0 software, synthesised by BGI. The primer sequences are presented in Table 2 . The $25 \mu$ l PCR mixtures

Table 2. Primers used for real-time PCR analyses

\begin{tabular}{|c|c|c|c|c|c|c|}
\hline \multirow[b]{2}{*}{ Targets } & \multirow[b]{2}{*}{ Accession no. } & \multicolumn{2}{|c|}{ Primer sequence $\left(5^{\prime} \rightarrow 3^{\prime}\right)$} & \multirow[b]{2}{*}{ Product size (bp) } & \multirow[b]{2}{*}{$T_{\mathrm{m}}\left({ }^{\circ} \mathrm{C}\right)$} & \multirow[b]{2}{*}{$E(\%)$} \\
\hline & & Forward & Reverse & & & \\
\hline IGF-1 & NM_214256.1 & TGCTTCCGGAGCTGTGATCT & CCGACTTGGCAGGCTTGA & 67 & $62 \cdot 5$ & $91 \cdot 3$ \\
\hline$Z O-1$ & XM_003353439.2 & CCTGAGTTTGATAGTGGCGTTGA & AAATAGATTTCCTGCCCAАTTCC & 269 & 59.4 & $91 \cdot 2$ \\
\hline Occludin & NM_001163647.2 & ACCCAGCAACGACATA & TCACGATAACGAGCATA & 155 & $56 \cdot 9$ & 92.5 \\
\hline IL-6 & NM_001252429.1 & CTTCAGTCCAGTCGCCTTCTCC & GCATCACCTTTGGCATCTTCTT & 96 & 62.5 & $94 \cdot 7$ \\
\hline$T N F-\alpha$ & NM_214022.1 & CCACGCTCTTCTGCСТАCTGC & CGACGGGCTTATCTGAGGTTTG & 132 & $61 \cdot 3$ & 93.6 \\
\hline IL-10 & NM_214041.1 & TCAAACGAAGGACCAGAT & GAAGATGTCAAACTCACCC & 328 & 59.4 & 92.5 \\
\hline TGF- $\beta 1$ & NM 214015.1 & GGACCTTATCCTGAATGCCTT & TAGGTTACCACTGAGCCACAAT & 133 & 62.5 & $90 \cdot 9$ \\
\hline$T B P$ & XM_003361418.1 & СTTACCCACCAACAGTTCAGT & GCTCTGACTTTAGCACCTGTT & 134 & $59 \cdot 4$ & $91 \cdot 0$ \\
\hline
\end{tabular}

$T_{\mathrm{m}}$, melting temperature; $E$, PCR efficiency; IGF-1, insulin-like growth factor 1 ; ZO-1, zonula occludens protein-1; TGF- $\beta 1$, transforming growth factor $\beta$; TBP, TATA boxbinding protein (reference gene). 
contained $12.5 \mu$ l of $2 \times \mathrm{SYBR}^{\circledR}$ premix Ex Taq ${ }^{\mathrm{TM}} \mathrm{II}, 10 \mu \mathrm{mol} / 1$ of each forward and reverse primer and $2 \mu \mathrm{l}$ of complementary DNA template. The PCR cycle parameters were as follows: an initial denaturation step at $95^{\circ} \mathrm{C}$ for $10 \mathrm{~s}$, forty cycles of $95^{\circ} \mathrm{C}$ for $5 \mathrm{~s}$ and $58-63^{\circ} \mathrm{C}$ for $30 \mathrm{~s}$ (Table 2). A melt curve analysis was generated following each real-time quantitative PCR assay to verify the specificity and purity of the resulting PCR products. Relative quantification of the target gene transcript with a chosen reference gene transcript $(T B P)$ was performed using the $\Delta \Delta C_{\mathrm{T}}$ method. All of the samples were analysed in triplicate. The mean threshold cycle $\left(C_{\mathrm{T}}\right)$ of triplicates of each sample was used for calculations.

\section{Analysis of PCR-denaturing gradient gel electrophoresis}

Jejunal digesta and faecal samples (approximately $5 \mathrm{~g}$ ) were aseptically obtained from the jejunum (middle section) and rectum of the twenty-eight piglets immediately post-slaughter, stored in sterile microtubes on ice, and transported immediately to the laboratory.

Total DNA was extracted from jejunal digesta and faecal samples using the QIAamp DNA Stool Mini Kit (Qiagen), according to the manufacturer's instructions ${ }^{(15)}$. The universal bacterial primers HDAI-GC (5'-CGCCCGGGGCGCGCCCCGGGCGGGGCGGGG GCACGGGGGGACTCCTACGGGAGGCAGCAGT-3') and HDA2 (5'-GTATTACCGCGGCTGCTGGCAC-3') were used to amplify the $\mathrm{V} 3$ regions of $16 \mathrm{~S}$ ribosomal $\mathrm{DNA}^{(16)}$. The reaction mixture $(50 \mu \mathrm{l})$ contained $5 \mu \mathrm{l}$ of 10 -fold PCR buffer, $4 \mu \mathrm{l}$ of dNTP mixture $(10 \mathrm{mmol} / \mu \mathrm{l}), 2 \mu \mathrm{l}$ of DNA template, $2 \mu \mathrm{l}$ of each primer $(2 \mu \mathrm{mol} / \mathrm{l}), 1 \mu \mathrm{l}$ of Taq polymerase and $34 \mu \mathrm{l}$ of distilled deionised water. The PCR was carried out on a S1000 ${ }^{\mathrm{TM}}$ Thermal Cycler System (Bio-Rad) with a programme set at $94^{\circ} \mathrm{C}$ for $4 \mathrm{~min}$, thirty cycles at $94^{\circ} \mathrm{C}$ for $30 \mathrm{~s}, 58^{\circ} \mathrm{C}$ for $30 \mathrm{~s}$ and $72^{\circ} \mathrm{C}$ for $2 \mathrm{~min}$. Subsequently, V3 amplicons of $16 \mathrm{~S}$ ribosomal DNA were used for sequence-specific separation by DGGE, which were performed on $10 \%$ polyacrylamide gels with $35-65 \%$ linear gradients of denaturant (100\% denaturant corresponds to $7 \mathrm{~m}$-urea and $40 \%$ deionised formamide) in 1-fold Tris acetate-EDTA buffer using a Bio-Rad D-Code System ${ }^{\text {TM }}$ (Bio-Rad) at $60^{\circ} \mathrm{C}$ for $16 \mathrm{~h}$ at $100 \mathrm{~V}$. The gel was developed after completion of electrophoresis and stained with $\mathrm{AgNO}_{3}$ according to the method described previously ${ }^{(17)}$. Microbiota richness and the Shannon diversity index were calculated by the number of DGGE bands and the amount in each band, both of which were obtained by the image analysis of DGGE gels performed with Gel-Pro Analyzer 4.0 (Media Cybernetics). For the cluster of DGGE profiles, bands in each DGGE gel were scored as 1 (present) or 0 (absent) ${ }^{(10)}$, and these DGGE data were used to compile a binary matrix for cluster analysis with a NTSYS-pc 2.10 package (Exeter software). Similarity among the DGGE profiles was calculated according to Jaccard's similarity coefficients, using the SIMQUAL (Similarity for Qualitative Data) routine. Then, the similarity coefficients were used to construct a dendrogram using the UPGMA (unweighted pair group method with arithmetic average) through the SHAN (sequential, hierarchical, agglomerative and nested clustering) routine of the NTSYS-pc package.
Analysis of the relative abundances of Lactobacillus and Escherichia coli

Genomic DNA was extracted from faecal samples ( $0 \cdot 2 \mathrm{~g}$ each) using a TIANamp Stool DNA Kit (Tiangen Biotech), according to the manufacturer's instructions.

The Lactobacillus primers FQ-RSF (GAGGCAGCAGTAGGGAATCTTC) and FQ-RSR (CAACAGTTA CTCTGACACCCGTTCTTC) and the $E$. coli primers FQ-DCF (CATGCCGCGTGTATGAAGAA) and $F Q-D C R$ (CGGGTAACGTCAATGAGCAAA) ${ }^{(18)}$ were used to perform real-time quantitative PCR by the $\Delta \Delta C_{\mathrm{T}}$ method for determining the relative abundances of the two types of bacteria with universal bacteria in the intestine of weaned piglets ${ }^{(19)}$. The universal bacterial primers were $\mathrm{Eub338F}$ (ACTCCTACGGGAGGCAGCAG) and Eub518R (ATTACCGCGGCTG CTGG) $^{(20)}$. The PCR efficiencies of Lactobacillus, E. coli and universal bacteria were 95.7, 93.5 and $93.2 \%$, respectively.

\section{Statistical analyses}

Data were analysed by a one-way ANOVA procedure using SPSS 17.0 software (SPSS, Inc.). Differences between means were tested using Duncan's range test. Significance was reported at $P<0.05$. Planned contrast was used to compare the LZ and HZ treatments. Polynomial (linear, quadratic and cubic) contrasts were used to determine the effect of the coated $\mathrm{ZnO}$ dose.

\section{Results}

\section{Growth performance and diarrhoea index}

No significant difference was observed in the growth performance of weaned piglets in all the groups, such as average daily gain, average daily feed intake and feed:gain ratio (Table 3 ). There was no incidence of diarrhoea in the present study as the diarrhoea index of all the groups remained low $(<1)$. Nonetheless, the HZ-fed group had a lower diarrhoea index than the LZ-fed group $(P<0 \cdot 01)$. The diarrhoea index decreased steadily as the level of coated $\mathrm{ZnO}$ was increased from 250 to $570 \mathrm{mg} \mathrm{Zn} / \mathrm{kg}$, and then increased with further addition (quadratic and cubic; $P<0 \cdot 01$ ). Compared with the LZ-fed group, the CZ380- and CZ570-fed groups had lower diarrhoea indices $(P<0.05)$, but were not significantly different from that of the HZ-fed group. Among the five groups supplemented with the coated $\mathrm{ZnO}$ diet, the CZ570fed group, having the minimum value of the diarrhoea index, had $40.63 \%$ lower diarrhoea index than the LZ-fed group $(P<0 \cdot 05)$.

\section{Intestinal morphology of weaned piglets}

The effects of coated $\mathrm{ZnO}$ supplementation on the smallintestinal morphology of weaned piglets are displayed in Table 4. The villus heights of the duodenum and ileum increased with the increasing amounts of coated $\mathrm{ZnO}$ supplementation. Moreover, duodenal villus height was greater for the groups supplemented with the coated $\mathrm{ZnO}$ diet 
Table 3. Growth performance and diarrhoea index of weaned piglets fed different levels of coated zinc oxide

(Mean values with their standard errors)

\begin{tabular}{|c|c|c|c|c|c|c|c|c|c|c|c|c|}
\hline \multirow[b]{2}{*}{ Items } & \multicolumn{9}{|c|}{ Treatment } & \multicolumn{3}{|c|}{ Contrast } \\
\hline & LZ & $\mathrm{HZ}$ & CZ250 & CZ380 & CZ570 & CZ760 & CZ1140 & SEM & LZ v. HZ & $L$ & $Q$ & $C$ \\
\hline Initial BW (kg) & $7 \cdot 71$ & $7 \cdot 72$ & $7 \cdot 76$ & $7 \cdot 67$ & 7.69 & $7 \cdot 70$ & 7.74 & 0.01 & 0.13 & 0.86 & 0.06 & 0.45 \\
\hline Final BW (kg) & $12 \cdot 2$ & $11 \cdot 8$ & 11.9 & $12 \cdot 4$ & $12 \cdot 1$ & $12 \cdot 5$ & $11 \cdot 7$ & 0.13 & 0.44 & 0.90 & 0.12 & 0.70 \\
\hline ADG $(g)$ & 319 & 289 & 294 & 336 & 312 & 344 & 286 & 9.07 & 0.43 & 0.91 & 0.07 & 0.75 \\
\hline ADFI (g) & 497 & 504 & 492 & 524 & 475 & 512 & 488 & $11 \cdot 6$ & 0.89 & $0 \cdot 86$ & 0.83 & 0.84 \\
\hline$F: G$ & 1.56 & $1 \cdot 77$ & 1.68 & 1.57 & 1.82 & 1.49 & 1.72 & 0.04 & $0 \cdot 16$ & 0.97 & 0.85 & 0.62 \\
\hline Diarrhoea index & $0.64^{\mathrm{a}}$ & $0.46^{\mathrm{b}}$ & $0.68^{a}$ & $0.39^{b}$ & $0.38^{b}$ & $0.67^{a}$ & $0.70^{\mathrm{a}}$ & 0.03 & $<0.01$ & 0.02 & $<0.01$ & $<0.01$ \\
\hline
\end{tabular}

$\mathrm{LZ}$, piglets fed at a dose of $250 \mathrm{mg} \mathrm{Zn} \mathrm{(ZnO)/kg;} \mathrm{HZ,} \mathrm{piglets} \mathrm{fed} \mathrm{at} \mathrm{a} \mathrm{dose} \mathrm{of} 2250 \mathrm{mg} \mathrm{Zn} \mathrm{(ZnO)/kg;} \mathrm{CZ250,} \mathrm{piglets} \mathrm{fed} \mathrm{at} \mathrm{a} \mathrm{dose} \mathrm{of} 250 \mathrm{mg} \mathrm{Zn}$ (coated ZnO)/kg of basal diet; $\mathrm{CZ380}$, piglets fed at a dose of $380 \mathrm{mg} \mathrm{Zn} \mathrm{(coated} \mathrm{ZnO)/kg} \mathrm{of} \mathrm{basal} \mathrm{diet;} \mathrm{CZ570,} \mathrm{piglets} \mathrm{fed} \mathrm{at} \mathrm{a} \mathrm{dose} \mathrm{of} 570 \mathrm{mg} \mathrm{Zn} \mathrm{(coated} \mathrm{ZnO)/kg} \mathrm{of} \mathrm{basal} \mathrm{diet;} \mathrm{CZ760,} \mathrm{piglets} \mathrm{fed} \mathrm{at} \mathrm{a}$ dose of $760 \mathrm{mg} \mathrm{Zn} \mathrm{(coated} \mathrm{ZnO)/kg} \mathrm{of} \mathrm{basal} \mathrm{diet;} \mathrm{CZ1140,} \mathrm{piglets} \mathrm{fed} \mathrm{at} \mathrm{a} \mathrm{dose} \mathrm{of} 1140 \mathrm{mg} Z \mathrm{n}$ (coated ZnO)/kg of basal diet; $L$, linear; $Q$, quadratic; $C$, cubic; BW, body weight; ADG, average daily gain; ADFI, average daily feed intake; F:G, feed:gain ratio.

${ }^{a, b}$ Mean values within a row with unlike superscript letters were significantly different $(P<0.05)$.

(except the CZ250-fed group) than for the LZ-fed group $(P<0.05)$; furthermore, the CZ760-fed group had a greater duodenal villus height than the HZ-fed group $(P<0 \cdot 05)$.

Additionally, the groups supplemented with the coated $\mathrm{ZnO}$ diet (except the CZ380-fed group) had decreased jejunal and ileal crypt depths $(P<0 \cdot 05)$ when compared with the LZ-fed group, and especially, the ileal crypt depths of these groups were not different from that of the HZ-fed group. In the duodenum, the ratio of villus height:crypt depth $(V: C)$ significantly increased with the increasing levels of coated $\mathrm{ZnO}$ up to $760 \mathrm{mg} \mathrm{Zn} / \mathrm{kg}$, and decreased thereafter $(P<0 \cdot 05)$. The $V: C$ values were higher for the coated ZnO-supplemented groups than for the LZ-fed group (except the CZ250-fed group), but none of the groups had a higher value than the HZ-fed group $(P<0.05)$. In the jejunum and ileum, the $V: C$ values for the CZ250-, CZ570- and CZ1140-fed groups were not significantly different from that for the HZ-fed group $(P>0.05)$. There were cubic $(P<0.01)$ effects of the coated $\mathrm{ZnO}$ dose on all small-intestinal morphology indices, except for the duodenal and ileal crypt depths, and jejunal $V: C$ values. Duodenal crypt depth showed a quadratic $(P<0 \cdot 01)$ response to the coated $\mathrm{ZnO}$ dose, while ileal crypt depth had a cubic $(P<0.05)$ response.

\section{Zinc concentrations of liver, kidney, serum and faeces}

$\mathrm{Zn}$ concentrations in the serum, liver and kidney of weaned piglets fed different levels of coated $\mathrm{ZnO}$ were not significantly different from that of the LZ-fed group (Table 5; $P>0.05)$, but the HZ-fed group had higher zinc concentrations $(P<0.05)$ than all the coated $\mathrm{ZnO}$-supplemented groups except the CZ1140-fed group, as Zn concentration in the serum of the CZ1140-fed group was not significantly different when compared with the HZ-fed group. Zn concentrations in the faeces of weaned piglets increased linearly with the increasing levels of coated $\mathrm{ZnO}(P<0 \cdot 01)$. When coated $\mathrm{ZnO}$ was added at the level of $1140 \mathrm{mg} \mathrm{Zn} / \mathrm{kg}$, it reached the highest value $(5020 \mathrm{mg} \mathrm{Zn} / \mathrm{kg}$ ), which was $321 \%$ higher than that of the LZ-fed group and $47 \%$ lower than that of the HZ-fed group. Nevertheless, Zn concentration in the faeces of the CZ380-fed group was $79 \%$ lower than that of the HZ-fed group.

\section{Secretory IgA concentrations in the jejunal mucosa of weaned piglets}

The concentrations of SIgA in the jejunal mucosa of weaned piglets fed different levels of coated $\mathrm{ZnO}$ are shown in Fig. 1. Compared with the LZ-fed group, the CZ380-,

Table 4. Small-intestinal morphology of weaned piglets fed different levels of coated zinc oxide

(Mean values with their standard errors)

\begin{tabular}{|c|c|c|c|c|c|c|c|c|c|c|c|c|}
\hline \multirow[b]{2}{*}{ Items } & \multicolumn{9}{|c|}{ Treatment } & \multicolumn{3}{|c|}{ Contrast } \\
\hline & LZ & $\mathrm{HZ}$ & CZ250 & CZ380 & CZ570 & CZ760 & CZ1140 & SEM & $\mathrm{LZ} v . \mathrm{HZ}$ & $L$ & $Q$ & $C$ \\
\hline Duodenal villus height $(\mu \mathrm{m})$ & $332^{\mathrm{c}}$ & $366^{\mathrm{b}}$ & $359^{b, c}$ & $387^{\mathrm{b}}$ & $371^{\mathrm{b}}$ & $456^{\mathrm{a}}$ & $372^{\mathrm{b}}$ & $7 \cdot 7$ & 0.02 & 0.02 & 0.01 & $<0.01$ \\
\hline Duodenal crypt depth $(\mu \mathrm{m})$ & $472^{\mathrm{a}}$ & $339^{c}$ & $469^{a}$ & $474^{\mathrm{a}}$ & $387^{\mathrm{b}}$ & $453^{\mathrm{a}}$ & $475^{a}$ & $10 \cdot 3$ & $<0.01$ & 0.80 & $<0.01$ & 0.16 \\
\hline Villus height:crypt depth ratio & $0.71^{f}$ & $1.09^{\mathrm{a}}$ & $0.77^{e, f}$ & $0.82^{c, d}$ & $0.96^{\mathrm{c}}$ & $1.01^{\mathrm{b}}$ & $0.79^{\mathrm{d}, \mathrm{e}}$ & 0.03 & $<0.01$ & 0.04 & $<0.01$ & $<0.01$ \\
\hline Jejunal villus height $(\mu \mathrm{m})$ & $305^{\mathrm{d}}$ & $427^{\mathrm{a}}$ & $322^{\mathrm{c}, \mathrm{d}}$ & $326^{c, d}$ & $371^{\mathrm{b}}$ & $267^{\mathrm{e}}$ & $358^{\mathrm{b}, \mathrm{c}}$ & $10 \cdot 0$ & $<0.01$ & 0.77 & 0.61 & $<0.01$ \\
\hline Jejunal crypt depth $(\mu \mathrm{m})$ & $342^{\mathrm{a}}$ & $322^{a, b}$ & $266^{d}$ & $314^{a, b}$ & $306^{\mathrm{b}}$ & $270^{\mathrm{c}, \mathrm{d}}$ & $300^{b, c}$ & $6 \cdot 0$ & 0.28 & 0.46 & 0.11 & $<0.01$ \\
\hline Villus height:crypt depth ratio & $0.90^{\mathrm{c}}$ & $1 \cdot 33^{\mathrm{a}}$ & $1 \cdot 22^{a, b}$ & $1.04^{\mathrm{b}, \mathrm{c}}$ & $1 \cdot 22^{a, b}$ & $1.00^{c}$ & $1 \cdot 20^{a, b}$ & 0.03 & $<0.01$ & 0.68 & 0.16 & 0.70 \\
\hline Ileal villus height $(\mu \mathrm{m})$ & $312^{\mathrm{c}}$ & $332^{\mathrm{C}}$ & $329^{c}$ & $271^{d}$ & $278^{d}$ & $374^{\mathrm{b}}$ & $414^{\mathrm{a}}$ & $9 \cdot 6$ & 0.06 & $<0.01$ & $<0.01$ & $<0.01$ \\
\hline Ileal crypt depth $(\mu \mathrm{m})$ & $323^{\mathrm{a}}$ & $246^{c}$ & $225^{\mathrm{c}}$ & $298^{a, b}$ & $232^{\mathrm{c}}$ & $261^{\mathrm{b}, \mathrm{c}}$ & $263^{b, c}$ & $7 \cdot 8$ & 0.01 & 0.33 & 0.31 & 0.01 \\
\hline Villus height:crypt depth ratio & $0.97^{\mathrm{c}, \mathrm{d}}$ & $1 \cdot 37^{\mathrm{a}, \mathrm{b}}$ & $1.47^{\mathrm{a}, \mathrm{b}}$ & $0.91^{d}$ & $1 \cdot 21^{\mathrm{b}, \mathrm{c}}$ & $1.44^{\mathrm{a}, \mathrm{b}}$ & $1 \cdot 61^{a}$ & 0.05 & $<0.01$ & 0.01 & $<0.01$ & $<0.01$ \\
\hline
\end{tabular}

$\mathrm{LZ}$, piglets fed at a dose of $250 \mathrm{mg} \mathrm{Zn} \mathrm{(ZnO)/kg;} \mathrm{HZ,} \mathrm{piglets} \mathrm{fed} \mathrm{at} \mathrm{a} \mathrm{dose} \mathrm{of} 2250 \mathrm{mg} \mathrm{Zn}(\mathrm{ZnO}) / \mathrm{kg} ; \mathrm{CZ250}$, piglets fed at a dose of 250 mg Zn (coated ZnO)/kg of basal diet; $\mathrm{CZ380}$, piglets fed at a dose of $380 \mathrm{mg} \mathrm{Zn} \mathrm{(coated} \mathrm{ZnO)/kg} \mathrm{of} \mathrm{basal} \mathrm{diet;} \mathrm{CZ570,} \mathrm{piglets} \mathrm{fed} \mathrm{at} \mathrm{a} \mathrm{dose} \mathrm{of} 570 \mathrm{mg} \mathrm{Zn} \mathrm{(coated} \mathrm{ZnO)/kg} \mathrm{of} \mathrm{basal} \mathrm{diet;} \mathrm{CZ760,} \mathrm{piglets} \mathrm{fed} \mathrm{at} \mathrm{a}$ dose of $760 \mathrm{mg} \mathrm{Zn} \mathrm{(coated} \mathrm{ZnO)/kg} \mathrm{of} \mathrm{basal} \mathrm{diet;} \mathrm{CZ1140,} \mathrm{piglets} \mathrm{fed} \mathrm{at} \mathrm{a} \mathrm{dose} \mathrm{of} 1140 \mathrm{mg} \mathrm{Zn} \mathrm{(coated} \mathrm{ZnO)/kg} \mathrm{of} \mathrm{basal} \mathrm{diet;} L$, linear; $Q$, quadratic; $C$, cubic. $\mathrm{a}, \mathrm{b}, \mathrm{c}, \mathrm{d}, \mathrm{e}, \mathrm{f}$ Mean values within a row with unlike superscript letters were significantly different $(P<0.05)$. 
Table 5. Zinc concentrations in the serum, liver, kidney and faeces of weaned piglets fed different levels of coated zinc oxide (Mean values with their standard errors)

\begin{tabular}{|c|c|c|c|c|c|c|c|c|c|c|c|c|}
\hline \multirow[b]{2}{*}{ Items } & \multicolumn{9}{|c|}{ Treatment } & \multicolumn{3}{|c|}{ Contrast } \\
\hline & LZ & $\mathrm{HZ}$ & CZ250 & CZ380 & CZ570 & CZ760 & CZ1140 & SEM & $\mathrm{LZ} v . \mathrm{HZ}$ & $L$ & $Q$ & $C$ \\
\hline Serum (mg/kg) & $0.73^{\mathrm{b}}$ & $1 \cdot 26^{\mathrm{a}}$ & $0.74^{\mathrm{b}}$ & $0.91^{\mathrm{b}}$ & $0.91^{\mathrm{b}}$ & $0.88^{\mathrm{b}}$ & $1.07^{\mathrm{a}, \mathrm{b}}$ & 0.05 & 0.03 & $<0.01$ & 0.92 & 0.01 \\
\hline Liver $(\mathrm{mg} / \mathrm{kg})$ & $91 \cdot 21^{\mathrm{b}}$ & $248 \cdot 91^{a}$ & $86 \cdot 02^{b}$ & $97 \cdot 75^{b}$ & $101.96^{\mathrm{b}}$ & $98 \cdot 50^{b}$ & $105 \cdot 34^{\mathrm{b}}$ & 11.4 & $<0.01$ & 0.16 & 0.61 & 0.51 \\
\hline Kidney (mg/kg) & $25 \cdot 54^{\mathrm{b}}$ & $39 \cdot 61^{a}$ & $27 \cdot 47^{\mathrm{b}}$ & $18 \cdot 14^{b}$ & $20 \cdot 74^{b}$ & $19 \cdot 53^{b}$ & $21 \cdot 26^{b}$ & $1 \cdot 6$ & 0.04 & $0 \cdot 16$ & 0.06 & 0.25 \\
\hline Faeces (mg/kg) & $1193^{f}$ & $9518^{a}$ & $1702^{e, f}$ & $1989^{\mathrm{e}}$ & $2839^{d}$ & $4077^{\mathrm{C}}$ & $5020^{\mathrm{b}}$ & 552.9 & $<0.01$ & $<0.01$ & 0.02 & 0.15 \\
\hline
\end{tabular}

$\mathrm{LZ}$, piglets fed at a dose of $250 \mathrm{mg} \mathrm{Zn} \mathrm{(ZnO)/kg;} \mathrm{HZ,} \mathrm{piglets} \mathrm{fed} \mathrm{at} \mathrm{a} \mathrm{dose} \mathrm{of} 2250 \mathrm{mg} \mathrm{Zn} \mathrm{(ZnO)/kg;} \mathrm{CZ250,} \mathrm{piglets} \mathrm{fed} \mathrm{at} \mathrm{a} \mathrm{dose} \mathrm{of} 250 \mathrm{mg} Z \mathrm{n}$ (coated ZnO)/kg of basal diet; $\mathrm{CZ380}$, piglets fed at a dose of $380 \mathrm{mg} \mathrm{Zn} \mathrm{(coated} \mathrm{ZnO)/kg} \mathrm{of} \mathrm{basal} \mathrm{diet;} \mathrm{CZ570,} \mathrm{piglets} \mathrm{fed} \mathrm{at} \mathrm{a} \mathrm{dose} \mathrm{of} 570 \mathrm{mg} Z \mathrm{n}$ (coated ZnO)/kg of basal diet; CZ760, piglets fed at a dose of $760 \mathrm{mg} \mathrm{Zn} \mathrm{(coated} \mathrm{ZnO}$ )/kg of basal diet; CZ1140, piglets fed at a dose of $1140 \mathrm{mg} \mathrm{Zn} \mathrm{(coated} \mathrm{ZnO)/kg} \mathrm{of} \mathrm{basal} \mathrm{diet;} L$, linear; $Q$, quadratic; $C$, cubic.

$\mathrm{a}, \mathrm{b}, \mathrm{c}, \mathrm{d}, \mathrm{e}, \mathrm{f}$ Mean values within a row with unlike superscript letters were significantly different $(P<0.05)$.

CZ570-, CZ760- and CZ1140-fed groups had higher SIgA concentrations in the jejunal mucosa $(P<0.05)$; of these, the CZ570-fed group had the highest concentration, but was not significantly difference from that of the HZ-fed group.

Gene expressions of insulin-like growth factor 1, tight junctions and inflammatory cytokines in the jejunal mucosa of weaned piglets fed different levels of coated zinc oxide

As shown in Table 6 , mRNA level of $I G F-1$ in the jejunal mucosa increased significantly $(P<0.05)$ as coated $\mathrm{ZnO}$ was added up to the level of $380 \mathrm{mg} \mathrm{Zn/kg}$, at which the IGF-1 mRNA level was the highest, and then kept decreasing consistently until it reached the lowest value $(1140 \mathrm{mg} \mathrm{Zn} / \mathrm{kg}$ ). Compared with the LZ- and HZ-fed groups, the CZ250-, CZ380- and CZ570-fed groups expressed higher IGF-1 mRNA levels $(P<0.05)$, and the mRNA levels of $I G F-1$ for the CZ380-fed group were approximately 345 and $189 \%$ higher than those for the LZ- and HZ-fed groups, respectively $(P<0.05)$. Additionally, the HZ-fed group had $54 \%$ higher $I G F-1$ mRNA level than the LZ-fed group $(P<0 \cdot 05)$. ZO-1 mRNA levels were up-regulated as coated $\mathrm{ZnO}$ was added at the level of $380 \mathrm{mg} \mathrm{Zn/kg}$, compared with that of the LZ-fed group $(P<0.05)$, but other levels of coated $\mathrm{ZnO}$ did not regulate the gene expression levels of $Z O-1$. Occludin mRNA levels were up-regulated in the coated $\mathrm{ZnO}$-fed groups, except the CZ1140-fed group, compared with that of the LZ-fed group $(P<0 \cdot 05)$. Moreover, occludin mRNA levels for the CZ380- and CZ570-fed groups were not significantly different compared with that of the HZ-fed group. TNF- $\alpha$ mRNA levels significantly decreased with the increasing levels of coated $\mathrm{ZnO}$ up to $570 \mathrm{mg} \mathrm{Zn/kg}(P<0.05)$, and plateaued subsequently. $I L-6$ mRNA levels showed a similar trend to the gene expression levels of $T N F-\alpha$, but plateaued later when the level of coated $\mathrm{ZnO}$ was increased up to $760 \mathrm{mg}$ $\mathrm{Zn} / \mathrm{kg}$. A similar change in trends was also observed in the gene expression levels of TGF- $\beta 1$ and $I L-10$ : TGF- $\beta 1$ mRNA level reached the peak when the level of coated $\mathrm{ZnO}$ was increased up to $380 \mathrm{mg} \mathrm{Zn} / \mathrm{kg}$, while $I L-10 \mathrm{mRNA}$ level did so when increased up to the level of $570 \mathrm{mg} \mathrm{Zn} / \mathrm{kg}$. Compared with the LZ-fed group, piglets fed the 250 and $380 \mathrm{mg} \mathrm{Zn}$ (coated $\mathrm{ZnO}) / \mathrm{kg}$ diets had significantly higher $T G F-\beta 1$ mRNA levels $(P<0.05)$, but were not significantly different from the other groups. IL-10 mRNA levels of all the coated ZnO-supplemented groups were higher than that of the LZ-fed group, whereas only the CZ570-fed group had a higher gene expression level of $I L-1 O$ than the HZ-fed group $(P<0.05)$. There were cubic effects $(P<0.05)$ of the coated $\mathrm{ZnO}$ dose on the gene expression levels of $I G F-1$, TJ and inflammatory cytokines, except $I L-10$ which showed a quadratic $(P<0 \cdot 01)$ response to the coated $\mathrm{ZnO}$ dose.

\section{Microbiota composition in the intestine}

The PCR-DGGE profiles of V3 amplicons obtained from the microbiota in the jejunum and faeces are presented in online supplementary Attachments 1 and 2. Microbiota richness and the Shannon diversity index determined by DGGE analyses in the jejunal digesta and faeces of weaned piglets fed different levels of coated $\mathrm{ZnO}$ are presented in Fig. 2. As shown in Fig. 2, almost all the piglets showed the same variation trend, and microbiota richness and the Shannon diversity index decreased with the increasing levels of coated $\mathrm{ZnO}$ up to $380 \mathrm{mg} \mathrm{Zn} / \mathrm{kg}$, and then continuously increased. As shown in Fig. 2(A), compared with the LZ-fed

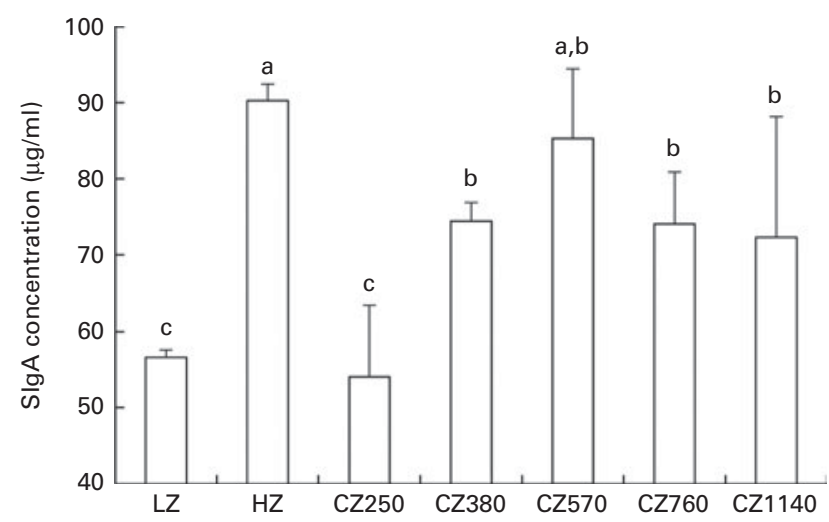

Fig. 1. Secretory $\operatorname{Ig} A(S \lg A)$ concentrations in the jejunal mucosa of weaned piglets fed different levels of coated zinc oxide $(\mathrm{ZnO})$. Values are means, with their standard errors represented by vertical bars. ${ }^{a, b, c}$ Mean values with unlike letters were significantly different $(P<0 \cdot 05)$. $\mathrm{LZ}$, piglets fed at a dose of $250 \mathrm{mg} \mathrm{Zn}(\mathrm{ZnO}) / \mathrm{kg}$; $\mathrm{HZ}$, piglets fed at a dose of $2250 \mathrm{mg} \mathrm{Zn}(\mathrm{ZnO}) / \mathrm{kg}$; $\mathrm{CZ250}$, piglets fed at a dose of $250 \mathrm{mg} \mathrm{Zn} \mathrm{(coated} \mathrm{ZnO}$ ) $/ \mathrm{kg}$ of basal diet; CZ380, piglets fed at a dose of $380 \mathrm{mg} \mathrm{Zn} \mathrm{(coated} \mathrm{ZnO}$ ) $/ \mathrm{kg}$ of basal diet; CZ570, piglets fed at a dose of $570 \mathrm{mg} \mathrm{Zn} \mathrm{(coated} \mathrm{ZnO)/kg} \mathrm{of} \mathrm{basal}$ diet; CZ760, piglets fed at a dose of $760 \mathrm{mg} \mathrm{Zn} \mathrm{(coated} \mathrm{ZnO}$ )/kg of basal diet; CZ1140, piglets fed at a dose of $1140 \mathrm{mg} \mathrm{Zn} \mathrm{(coated} \mathrm{ZnO)/kg} \mathrm{of} \mathrm{basal} \mathrm{diet.}$ 
Table 6. Gene expressions of insulin-like growth factor 1 (IGF-1), tight junctions and inflammatory cytokines in the jejunal mucosa of weaned piglets fed different levels of coated zinc oxide

(Mean values with their standard errors)

\begin{tabular}{|c|c|c|c|c|c|c|c|c|c|c|c|c|}
\hline \multirow[b]{2}{*}{ Genes* $^{*}$} & \multicolumn{9}{|c|}{ Treatment } & \multicolumn{3}{|c|}{ Contrast } \\
\hline & LZ & $\mathrm{HZ}$ & CZ250 & CZ380 & CZ570 & CZ760 & CZ1140 & SEM & $\mathrm{LZ} v . \mathrm{HZ}$ & $L$ & $Q$ & C \\
\hline$I G F-1$ & $1.00^{\mathrm{e}}$ & $1.54^{\mathrm{d}}$ & $2 \cdot 22^{\mathrm{C}}$ & $4 \cdot 45^{\mathrm{a}}$ & $3.23^{b}$ & $0.57^{e, f}$ & $0.28^{f}$ & 0.3 & 0.02 & $<0.01$ & $<0.01$ & $<0.01$ \\
\hline $20-1$ & $1.00^{\mathrm{b}, \mathrm{c}}$ & $1.90^{\mathrm{a}}$ & $1 \cdot 17^{\mathrm{b}}$ & $1.64^{a}$ & $0.63^{\mathrm{c}}$ & $0.77^{\mathrm{b}, \mathrm{c}}$ & $0.98^{\mathrm{b}, \mathrm{c}}$ & 0.1 & 0.02 & $<0.01$ & 0.14 & $<0.01$ \\
\hline Occludin & $1.00^{\mathrm{e}}$ & $2 \cdot 67^{\mathrm{a}, \mathrm{b}}$ & $1.73^{\mathrm{c}, \mathrm{d}}$ & $3 \cdot 12^{\mathrm{a}}$ & $2 \cdot 74^{\mathrm{a}, \mathrm{b}}$ & $2 \cdot 09^{b, c}$ & $1 \cdot 13^{\mathrm{d}, \mathrm{e}}$ & 0.2 & 0.01 & 0.01 & $<0.01$ & 0.04 \\
\hline$T N F-\alpha$ & $1.00^{c}$ & $0.43^{d}$ & $2 \cdot 51^{\mathrm{a}}$ & $2.06^{\mathrm{b}}$ & $0.43^{\mathrm{d}}$ & $0.32^{d}$ & $0.19^{d}$ & 0.2 & $<0.01$ & $<0.01$ & 0.01 & 0.01 \\
\hline IL-6 & $1.00^{\mathrm{d}}$ & $3.58^{\mathrm{a}}$ & $3.43^{a}$ & $2.92^{\mathrm{b}}$ & $1.58^{\mathrm{C}}$ & $0.98^{d}$ & $0.93^{d}$ & 0.3 & $<0.01$ & $<0.01$ & 0.01 & 0.01 \\
\hline$T G F-\beta 1$ & $1.00^{c, d}$ & $3.57^{a}$ & $1.63^{b}$ & $3.04^{a}$ & $1.34^{b, c}$ & $1 \cdot 17^{\mathrm{b}, \mathrm{c}, \mathrm{d}}$ & $0.57^{d}$ & 0.2 & 0.01 & $<0.01$ & $<0.01$ & $<0.01$ \\
\hline IL-10 & $1.00^{\mathrm{C}}$ & $1.92^{b}$ & $2 \cdot 52^{b}$ & $2 \cdot 36^{b}$ & $5 \cdot 66^{\mathrm{a}}$ & $1 \cdot 80^{\mathrm{b}, \mathrm{c}}$ & $2 \cdot 02^{b}$ & 0.3 & 0.03 & 0.16 & $<0.01$ & 0.51 \\
\hline
\end{tabular}

$\mathrm{LZ}$, piglets fed at a dose of $250 \mathrm{mg} \mathrm{Zn} \mathrm{(ZnO)/kg;} \mathrm{HZ,} \mathrm{piglets} \mathrm{fed} \mathrm{at} \mathrm{a} \mathrm{dose} \mathrm{of} 2250 \mathrm{mg} \mathrm{Zn} \mathrm{(ZnO)/kg;} \mathrm{CZ250,} \mathrm{piglets} \mathrm{fed} \mathrm{at} \mathrm{a} \mathrm{dose} \mathrm{of} 250 \mathrm{mg} \mathrm{Zn}$ (coated ZnO)/kg of basal diet; CZ380, piglets fed at a dose of $380 \mathrm{mg} \mathrm{Zn} \mathrm{(coated} \mathrm{ZnO)/kg} \mathrm{of} \mathrm{basal} \mathrm{diet;} \mathrm{CZ570,} \mathrm{piglets} \mathrm{fed} \mathrm{at} \mathrm{a} \mathrm{dose} \mathrm{of} 570 \mathrm{mg} \mathrm{Zn} \mathrm{(coated} \mathrm{ZnO)/kg} \mathrm{of} \mathrm{basal} \mathrm{diet;} \mathrm{CZ760,} \mathrm{piglets} \mathrm{fed} \mathrm{at} \mathrm{a}$ dose of $760 \mathrm{mg} Z \mathrm{n}$ (coated $\mathrm{ZnO}$ )/kg of basal diet; CZ1140, piglets fed at a dose of $1140 \mathrm{mg} \mathrm{Zn} \mathrm{(coated} \mathrm{ZnO)/kg} \mathrm{of} \mathrm{basal} \mathrm{diet;} L$, linear; $Q$, quadratic; $C$, cubic; ZO-1, zonula occludens protein-1; TGF- $\beta 1$, transforming growth factor $\beta 1$.

a,b,c,d,e,f Mean values within a row with unlike superscript letters were significantly different $(P<0.05)$.

${ }^{*}$ Relative mRNA levels were normalised using TBP (TATA box-binding protein, reference gene).

group, the CZ250 and CZ380-fed groups had lower microbiota richness in the jejunal digesta $(P<0.05)$, whereas only the CZ380-fed group had the lower value $(P<0.05)$ in the faeces (Fig. 2(B)). In the jejunal digesta, Shannon diversity indices were lower $(P<0.05)$ in the CZ250- and CZ380-fed groups than in the LZ-fed group, but were not significantly different from the other groups (Fig. 2(C)). In the faeces of the CZ380- and CZ570-fed groups, Shannon diversity indices were found to be lower $(P<0.05$; Fig. 2(D)). Among the coated ZnO-fed groups, the CZ380-fed group had the lowest

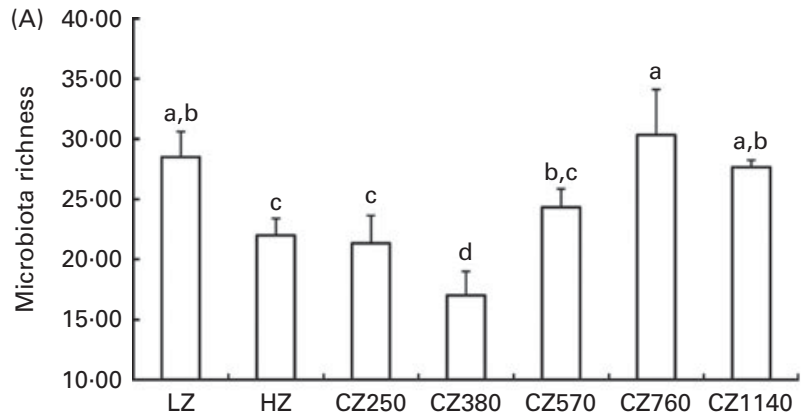

(C)

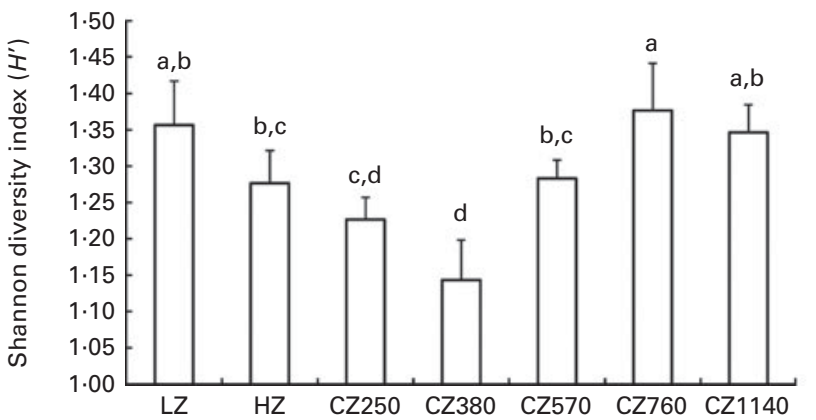

richness and Shannon diversity index of microbiota in both jejunal digesta and faeces.

Dendrograms showing the clustering of the DGGE profiles of the jejunal digesta and faeces are presented in Fig. 3. In the jejunal digesta, the similarity indices in the profiles of each group ranged from 0.68 to 0.82 , and the microbial communities of each group formed different small clusters according to the levels of coated $\mathrm{ZnO}$ added in the diets. The similarity index was the highest (0.82) for the microbial communities of the CZ250- and CZ380-fed groups,

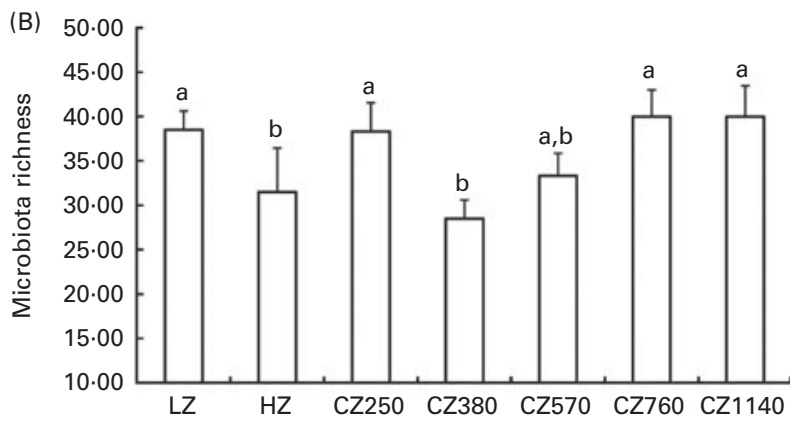

(D)

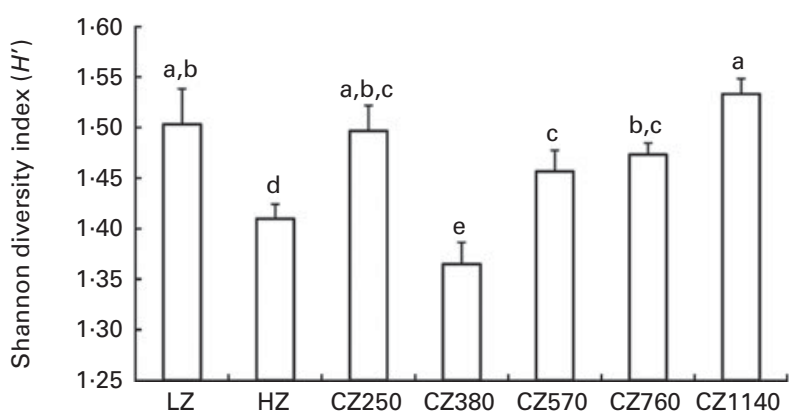

Fig. 2. Microbiota richness and Shannon diversity index determined by denaturing gradient gel electrophoresis analyses in (A, C) the jejunal digesta and (B, D) the faeces of weaned piglets fed different levels of coated zinc oxide ( $\mathrm{ZnO})$. Values are means, with their standard errors represented by vertical bars. ${ }^{a, b, c, d}$ Mean values with unlike letters were significantly different $(P<0.05)$. LZ, piglets fed at a dose of $250 \mathrm{mg} \mathrm{Zn}(\mathrm{ZnO}) / \mathrm{kg}$; $\mathrm{HZ}$, piglets fed at a dose of $2250 \mathrm{mg} \mathrm{Zn}(\mathrm{ZnO}) / \mathrm{kg}$; CZ250, piglets fed at a dose of $250 \mathrm{mg} \mathrm{Zn} \mathrm{(coated} \mathrm{ZnO)/kg} \mathrm{of} \mathrm{basal} \mathrm{diet;} \mathrm{CZ380,} \mathrm{piglets} \mathrm{fed} \mathrm{at} \mathrm{a} \mathrm{dose} \mathrm{of} 380 \mathrm{mg} \mathrm{Zn} \mathrm{(coated} \mathrm{ZnO)/kg} \mathrm{of} \mathrm{basal} \mathrm{diet;} \mathrm{CZ570,} \mathrm{piglets}$ fed at a dose of $570 \mathrm{mg} \mathrm{Zn} \mathrm{(coated} \mathrm{ZnO)/kg} \mathrm{of} \mathrm{basal} \mathrm{diet;} \mathrm{CZ760,} \mathrm{piglets} \mathrm{fed} \mathrm{at} \mathrm{a} \mathrm{dose} \mathrm{of} 760 \mathrm{mg} Z \mathrm{n}$ (coated ZnO)/kg of basal diet; CZ1140, piglets fed at a dose of $1140 \mathrm{mg} \mathrm{Zn} \mathrm{(coated} \mathrm{ZnO}) / \mathrm{kg}$ of basal diet. 


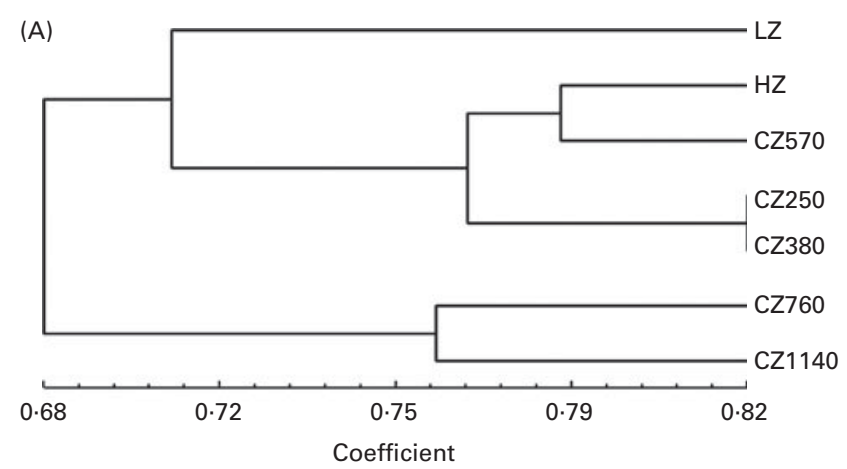

(B)

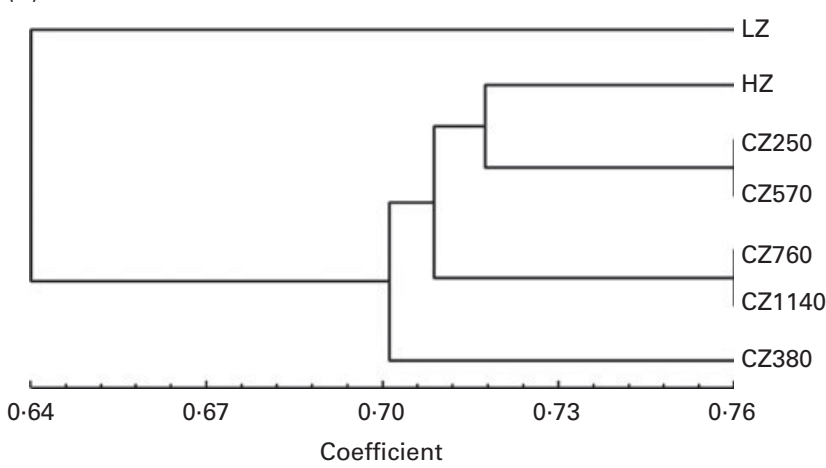

Fig. 3. Cluster analysis of denaturing gradient gel electrophoresis profiles of microbial communities in (A) the jejunal digesta and (B) the faeces of weaned piglets fed different levels of coated zinc oxide $(\mathrm{ZnO})$. LZ, piglets fed at a dose of $250 \mathrm{mg} \mathrm{Zn}(\mathrm{ZnO}) / \mathrm{kg} ; \mathrm{HZ}$, piglets fed at a dose of $2250 \mathrm{mg} \mathrm{Zn}$ $(\mathrm{ZnO}) / \mathrm{kg}$; CZ250, piglets fed at a dose of $250 \mathrm{mg} \mathrm{Zn} \mathrm{(coated} \mathrm{ZnO}$ )/kg of basal diet; CZ380, piglets fed at a dose of $380 \mathrm{mg} \mathrm{Zn} \mathrm{(coated} \mathrm{ZnO}$ )/kg of basal diet; CZ570, piglets fed at a dose of $570 \mathrm{mg} \mathrm{Zn} \mathrm{(coated} \mathrm{ZnO}$ )/kg of basal diet; CZ760, piglets fed at a dose of $760 \mathrm{mg} \mathrm{Zn} \mathrm{(coated} \mathrm{ZnO)/kg} \mathrm{of} \mathrm{basal} \mathrm{diet;}$ CZ1140, piglets fed at a dose of $1140 \mathrm{mg} \mathrm{Zn} \mathrm{(coated} \mathrm{ZnO)/kg} \mathrm{of} \mathrm{basal} \mathrm{diet.}$

and interestingly, those of the CZ570- and HZ-fed group clustered together, whose similarity index was about 0.79. In addition, microbial communities of the CZ760- and CZ1140-fed groups tended to form a cluster. In the faeces, similarly, some different small clusters were also formed, such as those of the CZ250- $v$. CZ570-fed group and the CZ760- $v$. CZ1140-fed group, with the similarity index of both being approximately $0 \cdot 76$. The microbial communities of the HZ-fed group formed a cluster with those of the
CZ250- v. CZ570-fed group, whose similarity index was approximately $0 \cdot 72$

As shown in Fig. 4, the relative abundances of Lactobacillus in faecal samples had a negative correlation with the levels of coated $\mathrm{ZnO}$ added, in which the CZ250-, CZ380- and CZ570-fed groups had the higher relative abundances than the LZ- and HZ-fed groups $(P<0 \cdot 05)$. The relative abundances of $E$. coli increased when coated $\mathrm{ZnO}$ was added at the levels of 380 and $570 \mathrm{mg} \mathrm{Zn/kg}$, but decreased when added up to the level of $760 \mathrm{mg} \mathrm{Zn} / \mathrm{kg}$. In addition, in the HZ-fed group, the relative abundance of Lactobacillus significantly decreased, in contrast to that of $E$. coli which significantly increased compared with the LZ-fed group $(P<0 \cdot 05)$.

\section{Discussion}

Early-weaned piglets, under the influence of weaning stress, usually encounter digestive disorders, diarrhoea and weakened immune system, which could jeopardise their health severely ${ }^{(1)}$. Piglet weaning stress is caused by three aspects of factors: psychology; nutrition; environment. $\mathrm{ZnO}$, as a kind of micronutrient $\mathrm{Zn}$ source, has been used to alleviate the stress of weaned piglets for a long period. Much research has shown that pharmacological doses of $\mathrm{Zn}$ (2000-4000 mg $\mathrm{Zn} / \mathrm{kg}$ ) from $\mathrm{ZnO}$, as a replacement of in-feed antibiotics, could improve growth performance and decrease the incidence of diarrhoea in piglets ${ }^{(4,21,22)}$. In the present study, no improvements in average daily gain, average daily feed intake or feed:gain ratio were found in the piglets of the HZ-fed group, which is consistent with some previous reports $^{(23,24)}$. There was no incidence of diarrhoea in the present study as the diarrhoea index of all the groups remained quite low $(<1)$, which could be due to the diets containing spray-dried plasma protein that can reduce the episodes of diarrhoea $^{(25)}$. However, the diarrhoea index decreased in the HZ-fed group, as well as in the coated $\mathrm{ZnO}$-fed groups (CZ380 and CZ570). The aforementioned results confirmed the assumption that $\mathrm{ZnO}$ probably functions at the site of the gastrointestinal tract to reduce the incidence of diarrhoea, mainly in its molecular form. A small percentage of $\mathrm{ZnO}$ can reach its site of action, because most of the $\mathrm{ZnO}$, which is
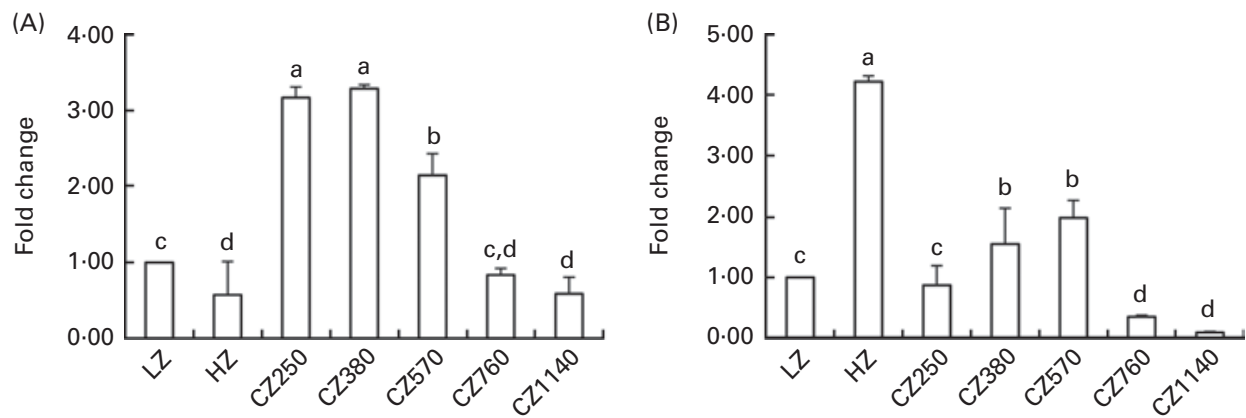

Fig. 4. Relative abundances of (A) Lactobacillus $\square$ and (B) Escherichia coli $\square$ in the faecal samples from weaned piglets fed different levels of coated zinc oxide $(\mathrm{ZnO})$. Values are means, with their standard errors represented by vertical bars. ${ }^{\mathrm{a}, \mathrm{b}, \mathrm{c}, \mathrm{d}}$ Mean values with unlike letters were significantly different $(P<0.05)$. $\mathrm{LZ}$, piglets fed at a dose of $250 \mathrm{mg} \mathrm{Zn} \mathrm{(ZnO)/kg;} \mathrm{HZ,} \mathrm{piglets} \mathrm{fed} \mathrm{at} \mathrm{a} \mathrm{dose} \mathrm{of} 2250 \mathrm{mg} \mathrm{Zn} \mathrm{(ZnO)/kg;} \mathrm{CZ250,} \mathrm{piglets} \mathrm{fed} \mathrm{at} \mathrm{a} \mathrm{dose} \mathrm{of} \mathrm{250} \mathrm{mg} \mathrm{Zn} \mathrm{(coated} \mathrm{ZnO)/kg} \mathrm{of}$ basal diet; CZ380, piglets fed at a dose of $380 \mathrm{mg} \mathrm{Zn} \mathrm{(coated} \mathrm{ZnO)/kg} \mathrm{of} \mathrm{basal} \mathrm{diet;} \mathrm{CZ570,} \mathrm{piglets} \mathrm{fed} \mathrm{at} \mathrm{a} \mathrm{dose} \mathrm{of} 570 \mathrm{mg} Z \mathrm{n}$ (coated ZnO)/kg of basal diet; $\mathrm{CZ760}$, piglets fed at a dose of $760 \mathrm{mg} \mathrm{Zn} \mathrm{(coated} \mathrm{ZnO)/kg} \mathrm{of} \mathrm{basal} \mathrm{diet;} \mathrm{CZ1140,} \mathrm{piglets} \mathrm{fed} \mathrm{at} \mathrm{a} \mathrm{dose} \mathrm{of} 1140 \mathrm{mg} Z \mathrm{n}$ (coated ZnO)/kg of basal diet. 
an easily dissociative substance in the gastric juice, is dissociated into free $\mathrm{Zn}$ ions when passing through the stomach. This is the reason why the addition level of $\mathrm{ZnO}$ has to reach up to $2000-4000 \mathrm{mg} \mathrm{Zn/kg}$ for the purpose of reducing the incidence of diarrhoea. When coated $\mathrm{ZnO}$ was added, as a replacement of $\mathrm{ZnO}$ (uncoated), the percentage of the $\mathrm{ZnO}$ molecule reaching the gastrointestinal tract is markedly increased, which is due to the protective enteric coating of the inner $\mathrm{ZnO}$. Therefore, in the present study, low levels of coated $\mathrm{ZnO}(380$ or $570 \mathrm{mg} \mathrm{Zn} / \mathrm{kg}$ ) were comparable with the pharmacological level of $\mathrm{ZnO}$ (uncoated, $2250 \mathrm{mg}$ $\mathrm{Zn} / \mathrm{kg}$ ) in alleviating the incidence of diarrhoea. Hu et al. ${ }^{(8)}$ reported that feeding diosmectite- $\mathrm{ZnO}$ at a low dose of $500 \mathrm{mg} \mathrm{Zn} / \mathrm{kg}$ alleviated the incidence of diarrhoea in piglets during days 0-14 post-weaning, which was similar to the feeding of $\mathrm{ZnO}$ at a high concentration (2250 $\mathrm{mg} \mathrm{Zn} / \mathrm{kg}$ ). Kim et al. ${ }^{(11)}$ demonstrated that the addition of lipid-coated $\mathrm{ZnO}$ at a dose of $100 \mathrm{mg} \mathrm{Zn} / \mathrm{kg}$ was dramatically effective in controlling post-weaning diarrhoea when piglets were challenged with the enterotoxigenic E. coli (ETEC) strain, compared with the addition of $\mathrm{ZnO}$ at a dose of $3000 \mathrm{mg}$ $\mathrm{Zn} / \mathrm{kg}$. The difference in the optimal addition level of coated $\mathrm{ZnO}$ in the two different studies may be caused by two factors: the difference in the ingredient and its proportion of enteric coating, and the difference in $\mathrm{Zn}$ concentration of the basal diet. In the present study, $\mathrm{Zn}$ concentration of the basal diet was $29.39 \mathrm{mg} / \mathrm{kg}$, whereas in the study of Kim et al. ${ }^{(11)}$, it was $198 \mathrm{mg} / \mathrm{kg}$. Additionally, we found that there were quadratic and cubic effects of coated $\mathrm{ZnO}$ on diarrhoea index. Once the dose of coated $\mathrm{ZnO}$ was increased to a certain level, no benefit would be found in alleviating the incidence of diarrhoea. As it is well known, supplementation with a pharmacological level of $\mathrm{ZnO}$ could cause excessive $\mathrm{Zn}$ residues in animals and environment pollution, because a large amount of unabsorbed $\mathrm{Zn}$ is excreted in the faeces. In the present study, the $\mathrm{Zn}$ concentrations in the serum, liver and kidney of the HZ-fed group were significantly higher than that of the LZ-fed group, but were not significantly different for all the coated $\mathrm{ZnO}$-fed groups when compared with the LZ-fed group. This observation demonstrated that animals were able to effectively regulate $\mathrm{Zn}$ absorption within the concentration limits of $\mathrm{Zn}$; nevertheless, once $\mathrm{Zn}$ dosage exceeds a certain threshold, the regulatory function would not work well. In addition, the results of the present study indicated that $\mathrm{Zn}$ concentrations in the faeces increased with the increasing levels of $\mathrm{Zn}$. Therefore, lower levels of $\mathrm{Zn}$ would result in lighter pollution of the heavy metal $\mathrm{Zn}$.

Small-intestinal epithelium is the main digestive and absorptive site of nutrients; moreover, it plays an important role as the intestinal immune barrier in resisting the invasion of environmental pathogens. Consequently, the integrity of the intestinal villus-crypt morphological structure is very important for animal health. Weaning stress is often associated with villus atrophy and crypt hyperplasia ${ }^{(26)}$, while a pharmacological level of $\mathrm{ZnO}$ can help control the symptoms: increasing villus height and reducing crypt depth in the small intestine of weaned piglets ${ }^{(27,28)}$. In the present study, piglets fed diets containing a high dose of $\mathrm{Zn}$ had a higher villus height and/or a lower crypt depth in the duodenum, jejunum and ileum than those fed the low-dose $\mathrm{Zn}$ diets, which corresponds with previous results, and villus heights in the duodenum of piglets fed the coated $\mathrm{ZnO}$ diets at the levels of 250, 380 or $570 \mathrm{mg} \mathrm{Zn/kg} \mathrm{did} \mathrm{not} \mathrm{differ} \mathrm{from} \mathrm{those} \mathrm{of} \mathrm{the} \mathrm{HZ-fed}$ piglets. This observation indicated that low levels of coated $\mathrm{ZnO}$ had similar effects to those of high levels of $\mathrm{ZnO}$ in improving intestine morphology. Gastrointestinal development of piglets is regulated by external and intrinsic factors ${ }^{(29)}$; the former mainly include intrauterine growth retardation, weaning stress and diet, while the latter are mediators involving enterocyte proliferation and differentiation. IGF-1, which can be synthesised locally in the gastrointestinal tract, is an important mediator of enterocyte proliferation and differentiation $^{(30)}$. The results of Li et $^{\text {al }}{ }^{(28)}$ suggested that $3000 \mathrm{mg}$ $\mathrm{Zn}(\mathrm{ZnO}) / \mathrm{kg}$ can enhance the mRNA expression of $I G F-1$ and $I G F-1$ receptor $(I G F-1 R)$ in the mucosa of weaned piglets. Alexander \& Carey ${ }^{(31)}$ demonstrated that oral IGF-1 significantly increased villus heights in the jejunum and ileum as well as the intestinal weight of piglets. In the present study, the induced gene up-regulation of $I G F-1$ in the jejunal mucosa was found in the HZ-, CZ250-, CZ380- and CZ570-fed groups. Furthermore, these three coated $\mathrm{ZnO}$-fed groups had higher IGF-1 mRNA levels than the HZ-fed group, and there were linear, quadratic and cubic effects of coated $\mathrm{ZnO}$ on the mRNA expression levels of $I G F-1$. These observations demonstrated that both high-dose $\mathrm{ZnO}$ and low-dose coated $\mathrm{ZnO}$ could enhance the mRNA expression levels of $I G F-1$ in the mucosa, while the improvements in small-intestinal morphology by feeding coated $\mathrm{ZnO}$ may be just partly attributed to an enhancement of $I G F-1$ expression in the gastrointestinal tract.

One of the major functions for the small-intestinal epithelium is serving as a barrier against noxious antigens and pathogens. Impairment of intestinal epithelium can increase intestinal permeability, which will promote the translocation of intestinal bacteria and the entering of toxic or allergenic substances from the gut into the body ${ }^{(32)}$. TJ, a network of proteins connecting the epithelial cells, plays a crucial role in maintaining gut barrier function. TJ mainly consists of transmembrane protein complexes and the cytosolic proteins $\mathrm{ZO}$, thus the expression levels of ZO-1 and occludin, the key proteins of $\mathrm{TJ}$, are consistently associated with barrier function ${ }^{(33)}$ It has been reported that the addition of $\mathrm{ZnO}$ at a dose of $2000 \mathrm{mg} \mathrm{Zn} / \mathrm{kg}$ reduced intestinal permeability by increasing the expression of the TJ proteins ZO-1 and occludin in weaned piglets ${ }^{(34)}$, which is, at least partly, the reason for reducing the incidence of diarrhoea. In the present study, both mRNA levels of ZO-1 and occludin were enhanced with the addition of $\mathrm{ZnO}$ at the level of $2250 \mathrm{mg} \mathrm{Zn} / \mathrm{kg}$, and the same effect was also found at the low level of coated $\mathrm{ZnO}(380 \mathrm{mg} \mathrm{Zn/kg}$ ). However, once the $\mathrm{ZnO}$ amount in the small intestine exceeds a certain level, TJ proteins will be impaired, resulting in the dysfunction of the intestinal mucosal immune barrier.

Absorptive enterocytes, the major group of intestinal epithelial cells, which cover the surface of the small intestine, can express polymeric Ig receptor ${ }^{(35)}$. This polymeric Ig receptor binds to the dimeric IgA secreted by lamina propria plasma 
cells, on the basal membrane of polarised intestinal epithelial cells for the transcytosis of dimeric IgA to apical membrane. Endoproteolytic cleavage of polymeric Ig receptor near the plasma membrane releases secretory component with cargo (dimeric IgA) into the lumen for the formation of the SIgA complex ${ }^{(36)}$. SIgA has been shown to play a crucial role in the mucosal immune system of the intestine as the first line of specific defence, including the ability to neutralise toxins produced by pathogenic bacteria and to prevent adherence and invasion by pathogenic bacteria. It has been reported that low concentrations of SIgA are associated with increased bacterial adherence to the mucosa ${ }^{(37)}$. SIgA secretion can be regulated by nutrients, such as fatty acids ${ }^{(38)}$, amino acids ${ }^{(39)}$ and vitamins ${ }^{(40)}$. As it is well known, Zn takes part in regulating intestinal mucosal immunity. In the present study, a high level of $\mathrm{ZnO}$ at $2250 \mathrm{mg} \mathrm{Zn/kg}$ and a lower level of coated $\mathrm{ZnO}$ at $570 \mathrm{mg} \mathrm{Zn} / \mathrm{kg}$ had almost the same function in upregulating the SIgA level, and intestinal SIgA levels were also increased when piglets received coated $\mathrm{ZnO}$ at the levels of 380, 760 and $1140 \mathrm{mg} \mathrm{Zn/kg}$. In contrast, previous studies showed that Zn supplementation had no effects on increasing levels of SIgA from the stool or urine of human subjects ${ }^{(41,42)}$. It may lead to different results that $\mathrm{Zn}$ supplementation comes from different $\mathrm{Zn}$ sources: $\mathrm{ZnO}$ or zinc acetate.

It has been reported that development of intestinal inflammation could be the consequence of abnormal penetration of commensal bacteria through the breakage of the intestinal epithelial barrier via an acceleration of apoptotic intestinal epithelial cells and subsequent hyperactivation of mucosal immune cells to produce acute and chronic pathological inflammatory reactions ${ }^{(35)}$. With the penetration of intense bacteria into intestinal tissues, hyperproduction of proinflammatory cytokines, such as TNF- $\alpha$ and IL-6, would be synthesised and then secreted in mucosal immune cells, causing further damage to the mucosal barrier system. Therefore, proinflammatory cytokines can be as the monitoring markers of inflammatory reactions ${ }^{(43)}$. In contrast, anti-inflammatory cytokines are suggested to play a vital role in antiinflammatory response during inflammation conditions. IL-10 suppresses the production of pro-inflammatory cytokines by means of inhibiting the translocation of NF- $\mathrm{BB}$, which is involved in the regulation of inflammatory cytokine expression $^{(44)}$. The present study has demonstrated that pharmacological concentration of $\mathrm{ZnO}$ inhibited the gene expression of $T N F-\alpha$, but enhanced that of $I L-1 O$ and $T G F-\beta 1$, which corresponds with the previous results. The gene upregulation of $I L-10, T G F-\beta 1, T N F-\alpha$ and $I L-6$ in the jejunal mucosa was observed in piglets fed diets containing coated $\mathrm{ZnO}$ at the levels of 250 and $380 \mathrm{mg} \mathrm{Zn/kg}$, whereas $T N F-\alpha$ mRNA level markedly decreased with the addition of coated $\mathrm{ZnO}$ up to the level of $570 \mathrm{mg} \mathrm{Zn} / \mathrm{kg}$, and $I L-10$ mRNA level was more than twice as much as that of $\mathrm{HZ}$ with the addition of coated $\mathrm{ZnO}$ at the level of $570 \mathrm{mg} \mathrm{Zn/kg}$. Sargeant et al. ${ }^{(45)}$ reported that $\mathrm{ZnO}$ reduced the inflammatory response of epithelial IPEC J2 cells (intestinal porcine epithelial cells) infected by ETEC, counteracted the up-regulation of $I L-6$ mRNA, but increased $T N F-\alpha$ mRNA level. Hu et al. ${ }^{(8)}$ suggested that the mRNA levels of $T N F-\alpha$ and $I L-6$ in the mucosa of piglets were reduced with the addition of $\mathrm{ZnO}$ at the level of $2250 \mathrm{mg}$ $\mathrm{Zn} / \mathrm{kg}$. In summary, lower concentration of coated $\mathrm{ZnO}$, to a certain extent, has the function of inhibiting the overproduction of pro-inflammatory cytokines and promoting the expression of anti-inflammatory cytokines.

Intestinal microecology, consisting of the four main components - the epithelium, the secretions, the nutrients and the microbiota, is a quite dynamic process ${ }^{(46)}$, so its balance is crucial in intestinal health. The microbiota is highly diverse, in health, it keeps constantly changing with the variables of intestinal ecology caused by geography and diet, but is dynamically stable. Once the stability of the intestinal microbiota is disturbed, it will lead to the overgrowth of indigenous and exogenous pathogenic bacteria, and animals will be more vulnerable to intestinal disease (diarrhoea) ${ }^{(47)}$. It has been proved that antibiotics can decrease the incidence of diarrhoea by way of exerting an impact on intestinal microbiota according to the decrease in richness and the Shannon diversity index ${ }^{(48)}$. The nutritional manipulation of animals during the weaning period could also change the composition of the microbiota in the gastrointestinal tract ${ }^{(49,50)}$. In the present study, microbiota species richness and the Shannon diversity index were used to assess microbiota diversity in the intestine of piglets, the former is a statistical estimator of the number of distinct species present, and the latter is a weighing of the abundance of distinct species. The results indicated that supplementation of coated $\mathrm{ZnO}$ at the level of $380 \mathrm{mg} \mathrm{Zn} / \mathrm{kg}$ or of $\mathrm{ZnO}$ at the level of $2250 \mathrm{mg} \mathrm{Zn} / \mathrm{kg}$ to weaned piglets reduced the microbiota species richness and Shannon diversity index in the jejunal digesta and faeces, suggesting that both high-dose $\mathrm{ZnO}$ and low-dose coated $\mathrm{ZnO}$ have an effect on intestinal microbiota diversity as antibiotics do. In addition, the cluster analysis of the DGGE profiles of the jejunal digesta and faeces demonstrated that the intestinal microbiota of piglets fed a low concentration of coated $\mathrm{ZnO}$ (250, 380 or $570 \mathrm{mg} \mathrm{Zn} / \mathrm{kg}$ ) had a higher similarity to that of piglets fed a high concentration of $\mathrm{ZnO}(2250 \mathrm{mg} \mathrm{Zn/kg})$. The abovementioned analysis indicated that a low concentration of coated $\mathrm{ZnO}$ can exert a vital impact on the composition of the intestinal microbiota, as does a high concentration of $\mathrm{ZnO}$. As enteropathogenic E. coli is one of the main factors causing diarrhoea in piglets, a hypothesis was put forward that pharmacological concentration of $\mathrm{ZnO}$ can protect weaned piglets against diarrhoea mainly by inhibiting the growth of enteropathogenic E. coli in the digestive tract. However, the results of many experimental studies did not support the hypothesis. Jensen-Waern et al. ${ }^{(51)}$ reported that supplementation of $2500 \mathrm{mg} \mathrm{Zn} \mathrm{(dietary} \mathrm{ZnO}$ )/ $\mathrm{kg}$ had no effect on the population of $E$. coli in the faeces. Similar results were observed in the study by Li et al. ${ }^{(27)}$, which reported that there was no effect of supplementary $\mathrm{ZnO}(3000 \mathrm{mg}$ $\mathrm{Zn} / \mathrm{kg}$ ) on Enterobacteriaceae and Lactobacillus populations in the ileal digesta or faeces. Interestingly, Højberg et al. ${ }^{(52)}$ found that the amounts of Lactobacillus were reduced, whereas the coliforms were more numerous in piglets, when receiving the high- $\mathrm{ZnO}$ dose $(2500 \mathrm{mg} \mathrm{Zn} / \mathrm{kg})$. The results of the study by Broom et al. ${ }^{(53)}$ suggested that supplementation with $3100 \mathrm{mg} \mathrm{Zn}(\mathrm{ZnO}) / \mathrm{kg}$ decreased the colony counts of 
lactic acid bacteria, especially the dominant species of Lactobacillus (Lactobacillus reuteri), but increased the relative abundance of Enterobacteriaceae spp., except for $E$. coli that was not affected. In the present study, when piglets were fed $\mathrm{ZnO}$ at a dose of $2250 \mathrm{mg} \mathrm{Zn/kg}$, the relative abundance of Lactobacillus was down-regulated, while that of E. coli was up-regulated, which were similar to the results reported by Højberg et al. ${ }^{(52)}$ Additionally, lower concentrations of coated $\mathrm{ZnO}$ (380 and $570 \mathrm{mg} \mathrm{Zn/kg}$ ) had significant positive effects on the growth of both Lactobacillus and E. coli. Therefore, from these results, we conclude that it is likely that $\mathrm{ZnO}$ protects weaned piglets from diarrhoea not by the direct antibacterial effect on E. coli. Roselli et al. ${ }^{(7)}$ found that $\mathrm{ZnO}$ treatment ( $1 \mathrm{~mm}$ ) reduced the number of ETEC adhesion and invasivity of Caco-2 cells, while the number of ETEC grown in a medium with and without $\mathrm{ZnO}(1 \mathrm{~mm})$ had no difference. This observation indicated that $\mathrm{ZnO}$ may not retard the growth or development of ETEC, but can inhibit the adhesion and internalisation of intestinal epithelial cells, and thus decrease the breakage of the intestinal epithelial barrier.

In conclusion, a low concentration of coated $\mathrm{ZnO}$ (380 or $570 \mathrm{mg} \mathrm{Zn} / \mathrm{kg}$ ) can alleviate diarrhoea by promoting intestinal development, protecting the intestinal mucosal barrier from damage, stimulating the mucosal immune system and regulating the intestinal microbiota, as does a high concentration of $\mathrm{ZnO}$. Moreover, compared with a high concentration of $\mathrm{ZnO}$, a low concentration of coated $\mathrm{ZnO}$ prevented the accumulation of excessive $\mathrm{Zn}$ in animals and reduced the $\mathrm{Zn}$ concentration of excreted faeces, so as to achieve the goal of saving $\mathrm{Zn}$ source and reducing environmental pollution of $\mathrm{Zn}$. Additionally, it must be noted that the dose of coated $\mathrm{ZnO}$ used in the present study reduced significantly compared with that of $\mathrm{ZnO}$ supported by clay mineral carriers in previous studies; however, it is still supra-physiological for piglets. The present results demonstrate that using coated $\mathrm{ZnO}$ is a feasible means to further reduce the dose of $\mathrm{ZnO}$ to near-physiological concentration of $\mathrm{Zn}$ for piglets.

\section{Supplementary material}

To view supplementary material for this article, please visit http://dx.doi.org/10.1017/S0007114514000300

\section{Acknowledgements}

The present study was supported by the Shuangzhi Project of Sichuan Agricultural University, and GuangZhou Wisdom BioTech Company Limited, which had a role in the design of this article.

The contributions of the authors were as follows: Z. W., A. Z., S. W. and Y. L. designed the trial; J. S., M. H., X. Z., Y. C. and A. Z. conducted the feeding experiment; J. S. and Y. C. were responsible for the laboratory analysis; J. S. analysed the data and wrote the manuscript; Z. W., B. X., L. W., L. M., X. Z., H. Z. and Q. P. revised the manuscript; H. Z. and Q. P. offered technical assistance.

None of the authors has any conflicts of interest to declare.

\section{References}

1. Owusu-Asiedu A, Nyachoti C \& Marquardt R (2003) Response of early-weaned pigs to an enterotoxigenic Escherichia coli (K88) challenge when fed diets containing spraydried porcine plasma or pea protein isolate plus egg yolk antibody, zinc oxide, fumaric acid, or antibiotic. J Anim Sci 81, 1790-1798.

2. Moeser AJ, Klok CV, Ryan KA, et al. (2007) Stress signaling pathways activated by weaning mediate intestinal dysfunction in the pig. Am J Physiol Gastrointest Liver Physiol 292, G173-G181.

3. Funderburke D \& Seerley R (1990) The effects of postweaning stressors on pig weight change, blood, liver and digestive tract characteristics. J Anim Sci $\mathbf{6 8}, 155-162$.

4. Carlson M, Hill G \& Link J (1999) Early- and traditionally weaned nursery pigs benefit from phase-feeding pharmacological concentrations of zinc oxide: effect on metallothionein and mineral concentrations. J Anim Sci 77, 1199-1207.

5. Hill G, Mahan D, Carter S, et al. (2001) Effect of pharmacological concentrations of zinc oxide with or without the inclusion of an antibacterial agent on nursery pig performance. J Anim Sci 79, 934-941.

6. Hahn JD \& Baker DH (1993) Growth and plasma zinc responses of young pigs fed pharmacologic levels of zinc. J Anim Sci 71, 3020-3024.

7. Roselli M, Finamore A, Garaguso I, et al. (2003) Zinc oxide protects cultured enterocytes from the damage induced by Escherichia coli. J Nutr 133, 4077-4082.

8. Hu C, Song J, Li Y, et al. (2013) Diosmectite-zinc oxide composite improves intestinal barrier function, modulates expression of pro-inflammatory cytokines and tight junction protein in early weaned pigs. Br J Nutr 110, 681-688.

9. Hu C, Xiao K, Song J, et al. (2013) Effects of zinc oxide supported on zeolite on growth performance, intestinal microflora and permeability, and cytokines expression of weaned pigs. Anim Feed Sci Technol 181, 65-71.

10. Kim TW, Lee JH, Park MH, et al. (2010) Analysis of bacterial and fungal communities in Japanese- and Chinese-fermented soybean pastes using nested PCR-DGGE. Curr Microbiol 60, 315-320.

11. Kim JC, Hansen CF, Mullan BP, et al. (2012) Nutrition and pathology of weaner pigs: nutritional strategies to support barrier function in the gastrointestinal tract. Anim Feed Sci Technol 173, 3-16.

12. National Research Council (1998) Nutrient Requirements of Swine, 10th ed. Washington, DC: National Academy Press.

13. Castillo M, Martin-Orue S, Taylor-Pickard J, et al. (2008) Use of mannanoligosaccharides and zinc chelate as growth promoters and diarrhea preventative in weaning pigs: effects on microbiota and gut function. J Anim Sci 86, 94-101.

14. Association of Official Analytical Chemists (1990) Official Methods of Analysis, 15th ed. Washington, DC: AOAC.

15. Li M, Gong J, Cottrill M, et al. (2003) Evaluation of QIAamp DNA Stool Mini Kit for ecological studies of gut microbiota. $J$ Microbiol Methods 54, 13-20.

16. Fang J, Yan F, Kong X, et al. (2009) Dietary supplementation with Acanthopanax senticosus extract enhances gut health in weanling piglets. Livest Sci 123, 268-275.

17. Wang HF, Zhu WY, Yao W, et al. (2007) DGGE and 16S rDNA sequencing analysis of bacterial communities in colon content and feces of pigs fed whole crop rice. Anaerobe 13, $127-133$.

18. Qi H, Xiang Z, Han G, et al. (2011) Effects of different dietary protein sources on cecal microflora in rats. Afr J Biotechnol 10, 3704-3708. 
19. Livak KJ \& Schmittgen TD (2001) Analysis of relative gene expression data using real-time quantitative PCR and the $2^{-\triangle \Delta C T}$ method. Methods 25, 402-408.

20. Fierer N, Jackson JA, Vilgalys R, et al. (2005) Assessment of soil microbial community structure by use of taxonspecific quantitative PCR assays. Appl Environ Microbiol 71, 4117-4120.

21. Case C \& Carlson M (2002) Effect of feeding organic and inorganic sources of additional zinc on growth performance and zinc balance in nursery pigs. J Anim Sci 80, 1917-1924.

22. Castillo M, Martín-Orúe SM, Manzanilla EG, et al. (2006) Quantification of total bacteria, enterobacteria and lactobacilli populations in pig digesta by real-time PCR. Vet Microbiol 114, 165-170.

23. Schell T \& Kornegay E (1996) Zinc concentration in tissues and performance of weanling pigs fed pharmacological levels of zinc from $\mathrm{ZnO}$, Zn-methionine, Zn-lysine, or $\mathrm{ZnSO}_{4}$. J Anim Sci 74, 1584-1593.

24. Tokach L, Tokach M, Goodband R, et al. (1992) Influence of zinc oxide in starter diets on pig performance. In American Association of Swine Practitioners Proceedings, p. 411.

25. Niewold TA, van Dijk AJ, Geenen PL, et al. (2007) Dietary specific antibodies in spray-dried immune plasma prevent enterotoxigenic F4 (ETEC) post weaning diarrhoea in piglets. Vet Microbiol 124, 3-4.

26. Montagne L, Boudry G, Favier C, et al. (2007) Main intestinal markers associated with the changes in gut architecture and function in piglets after weaning. BrJ Nutr 97, 45-57.

27. Li B, Van Kessel A, Caine W, et al. (2001) Small intestinal morphology and bacterial populations in ileal digesta and feces of newly weaned pigs receiving a high dietary level of zinc oxide. Can J Anim Sci 81, 511-516.

28. Li X, Yin J, Li D, et al. (2006) Dietary supplementation with zinc oxide increases IGF-I and IGF-I receptor gene expression in the small intestine of weanling piglets. J Nutr 136, 1786-1791.

29. Pluske JR, Hampson DJ \& Williams IH (1997) Factors influencing the structure and function of the small intestine in the weaned pig: a review. Livest Prod Sci 51, 215-236.

30. Jones JI \& Clemmons DR (1995) Insulin-like growth factors and their binding proteins: biological actions. Endocr Rev 16, 3-34.

31. Alexander AN \& Carey HV (1999) Oral IGF-I enhances nutrient and electrolyte absorption in neonatal piglet intestine. Am J Physiol 277, G619-G625.

32. Wijtten PJ, Meulen Jvd \& Verstegen MW (2011) Intestinal barrier function and absorption in pigs after weaning: a review. Br J Nutr 105, 967-981.

33. Musch MW, Walsh-Reitz MM \& Chang EB (2006) Roles of ZO-1, occludin, and actin in oxidant-induced barrier disruption. Am J Physiol Gastrointestinal Liver Physiol 290, G222-G231.

34. Zhang B \& Guo Y (2009) Supplemental zinc reduced intestinal permeability by enhancing occludin and zonula occludens protein-1 (ZO-1) expression in weaning piglets. Br J Nutr 102, 687-693.

35. Goto Y \& Kiyono H (2012) Epithelial barrier: an interface for the cross-communication between gut flora and immune system. Immunol Rev 245, 147-163.

36. Johansen FE \& Kaetzel CS (2011) Regulation of the polymeric immunoglobulin receptor and IgA transport: new advances in environmental factors that stimulate $p I g R$ expression and its role in mucosal immunity. Mucosal Immunol 4, 598-602.
37. Rodrigues AC, Cara DC, Fretez SH, et al. (2000) Saccharomyces boulardii stimulates SIgA production and the phagocytic system of gnotobiotic mice. J Appl Microbiol 89, 404-414.

38. Pérez-Cano FJ, Ramírez-Santana C, Molero-Luís M, et al. (2009) Mucosal IgA increase in rats by continuous CLA feeding during suckling and early infancy. J lipid Res 50, $467-476$.

39. Imaeda H, Miura S, Serizawa H, et al. (1993) Influence of fatty acid absorption on bidirectional release of immunoglobulin A into intestinal lumen and intestinal lymph in rats. Immunol lett 38, 253-258.

40. Yang Y, Yuan Y, Tao Y, et al. (2011) Effects of vitamin A deficiency on mucosal immunity and response to intestinal infection in rats. Nutrition 27, 227-232.

41. Bates C, Evans P, Dardenne M, et al. (1993) A trial of zinc supplementation in young rural Gambian children. $\mathrm{Br} J$ Nutr 69, 243-255.

42. Raqib R, Roy SK, Rahman MJ, et al. (2004) Effect of zinc supplementation on immune and inflammatory responses in pediatric patients with shigellosis. Am J Clin Nutr 79, $444-450$.

43. Borovikova LV, Ivanova S, Zhang M, et al. (2000) Vagus nerve stimulation attenuates the systemic inflammatory response to endotoxin. Nature 405, 458-462.

44. Oberholzer A, Oberholzer C \& Moldawer LL (2002) Interleukin-10: a complex role in the pathogenesis of sepsis syndromes and its potential as an anti-inflammatory drug. Crit Care Med 30, Suppl. 1, S58-S63.

45. Sargeant HR, Miller HM \& Shaw MA (2011) Inflammatory response of porcine epithelial IPEC J2 cells to enterotoxigenic $E$. coli infection is modulated by zinc supplementation. Mol Immunol 48, 2113-2121.

46. Floch MH (2011) Intestinal microecology in health and wellness. J Clin Gastroenterol 45, S108-S110.

47. Bhandari S, Xu B, Nyachoti C, et al. (2008) Evaluation of alternatives to antibiotics using an Escherichia coli K88 + model of piglet diarrhea: effects on gut microbial ecology. J Anim Sci 86, 836-847.

48. Wang HF, Wang JL, Wang C, et al. (2012) Effect of bamboo vinegar as an antibiotic alternative on growth performance and fecal bacterial communities of weaned piglets. Livest Sci 144, 173-180.

49. Lubbs D, Vester B, Fastinger N, et al. (2009) Dietary protein concentration affects intestinal microbiota of adult cats: a study using DGGE and QPCR to evaluate differences in microbial populations in the feline gastrointestinal tract. J Anim Physiol Anim Nutr 93, 113-121.

50. Gong J, Yu H, Liu T, et al. (2008) Characterization of ileal bacterial microbiota in newly-weaned pigs in response to feeding lincomycin, organic acids or herbal extract. Livest Sci 116, 318-322.

51. Jensen-Waern M, Melin L, Lindberg R, et al. (1998) Dietary zinc oxide in weaned pigs - effects on performance, tissue concentrations, morphology, neutrophil functions and faecal microflora. Res Vet Sci 64, 225-231.

52. Højberg O, Canibe N, Poulsen HD, et al. (2005) Influence of dietary zinc oxide and copper sulfate on the gastrointestinal ecosystem in newly weaned piglets. Appl Environ Microbiol 71, 2267-2277.

53. Broom LJ, Miller HM, Kerr KG, et al. (2006) Effects of zinc oxide and Enterococcus faecium SF68 dietary supplementation on the performance, intestinal microbiota and immune status of weaned piglets. Res Vet Sci $\mathbf{8 0}, 45-54$. 